\title{
Whole Tumor Antigen Vaccines
}

\author{
Cheryl Lai-Lai Chiang, Fabian Benencia, and George Coukos \\ Ovarian Cancer Research Center, University of Pennsylvania Medical Center
}

\begin{abstract}
Although cancer vaccines with defined antigens are commonly used, the use of whole tumor cell preparations in tumor immunotherapy is a very promising approach and can obviate some important limitations in vaccine development. Whole tumor cells are a good source of TAAs and can induce simultaneous CTLs and $\mathrm{CD} 4^{+} \mathrm{T}$ helper cell activation. We review current approaches to prepare whole tumor cell vaccines, including traditional methods of freeze-thaw lysates, tumor cells treated with ultraviolet irradiation, and RNA electroporation, along with more recent methods to increase tumor cell immunogenicity with $\mathrm{HOCl}$ oxidation or infection with replicationincompetent herpes simplex virus.
\end{abstract}

\section{Keywords}

ovarian carcinoma; whole tumor cell vaccine; dendritic cell; necrosis; apoptosis

\section{Introduction}

Accumulating evidence shows that a proportion of many common solid tumor types are spontaneously recognized and attacked by the immune system and this is associated with improved clinical outcomes. For example, in ovarian cancer, we identified intraepithelial lymphocytes (infiltrating tumor islets) in tumors expressing a molecular signature of $\mathrm{T}$ cell activation, including IFN- $\gamma$, IL-2 and effector lymphocyte-associated chemokines [1]. Ovarian cancer tumor-infiltrating lymphocytes (TILs) are oligoclonal [2], recognize autologous tumor antigens [3-5], and display tumor-specific cytolytic activity ex vivo [5-7]. The presence of intraepithelial TILs is associated with significantly longer clinical remission after chemotherapy as well as improved overall survival of the patients in ovarian cancer [1], an observation validated by different studies in ovarian cancer [8-15] and other tumors such as melanoma, breast, prostate, renal cell, esophageal and colorectal carcinoma [16-22]. The association of spontaneous antitumor immune response with improved survival implies that many patients could benefit from strengthening tumor rejection through immunotherapy.

Tumors are recognized by the immune system through unique tumor associated antigens (TAAs) (reviewed in [23]). TAAs can be divided into five major categories: (1) mutated antigens expressed uniquely by tumors; (2) overexpressed antigens, i.e. normal proteins whose expression is upregulated in tumor; (3) oncofetal antigens shared by embryonic or

(C) 2010 Published by Elsevier Ltd.

Address: Biomedical Research Building II/III, Room 1325, 421 Curie Boulevard, Philadelphia, PA 19104-6142, *Tel.: +1 215 662 3316, fax: +1 215573 7627, gcks@mail.med.upenn.edu.

Publisher's Disclaimer: This is a PDF file of an unedited manuscript that has been accepted for publication. As a service to our customers we are providing this early version of the manuscript. The manuscript will undergo copyediting, typesetting, and review of the resulting proof before it is published in its final citable form. Please note that during the production process errors may be discovered which could affect the content, and all legal disclaimers that apply to the journal pertain. 
fetal tissues and; (4) differentiation or lineage antigens; and (5) cancer-testis antigens shared by spermatocytes/spermatogonia and tumor cells. With rapid advancements in molecular biology and the development of new genomic and proteomic interrogation technologies such as gene expression microarray, differential display, SAGE, mass spectrometry etc. as well as techniques to interrogate immune response through serum autoantibodies such as SEREX (serological analysis of autologous tumor antigens in serum of cancer patients by recombinant cDNA expression cloning), many additional TAA targets are rapidly identified and added in the design of new immunotherapeutic strategies. However, painstaking work remains to be done to fully characterize the immunogenicity of these emerging antigens in the human, identify the most immunogenic epitopes, and test their role as bona fide tumor rejection antigens that can cause tumor regression.

The most popular and widely used TAAs for tumor vaccines are HLA-restricted immunodominant peptides. It is relatively easy to synthesize large quantities of clinical grade peptides, but there are several disadvantages associated with their use. First, only patients possessing specific HLA expression(s) are eligible. Second, the resulting immune responses are limited to the epitope(s) used for immunization that might be insufficient to rapidly eliminate tumors, and could drive the emergence of escape variants of the tumor cells. Indeed, the phenomenon of epitope spreading is only observed in very small numbers of patients after single or multiple peptide immunization [24,25]. Finally, the longevity of MHC-peptide complexes in vivo is unknown. The affinity of peptides for their various HLA molecules also varies and this could affect their immunogenicity in vivo, should competition occur between/amongst the peptides. Some research groups have incorporated peptides encoding epitopes recognized by $\mathrm{CD} 4^{+} \mathrm{T}$ helper cells to elicit a stronger overall immune response through providing cognate help to $\mathrm{CD} 8^{+} \mathrm{T}$ cells. However, few authentic tumor antigen $\mathrm{CD}_{4}{ }^{+}$epitopes have been defined to date. Peptide-based trials have met with limited success and the issues previously mentioned still need to be addressed. Vaccination with the full length protein or open reading frame RNA or cDNA of candidate TAAs is a valid alternative, but still faces similar challenges regarding the need for painstaking characterization of individual TAAs.

A promising alternative to individual TAAs is vaccination using derivatives of whole tumor cells without defining the antigens. Tumor cells express a whole array of TAAs that are both characterized and uncharacterized, and this rich source of antigens contains epitopes of both $\mathrm{CD} 8^{+}$cytotoxic $\mathrm{T}$ cells (CTLs) and $\mathrm{CD} 4^{+} \mathrm{T}$ helper cells. This is important, as the parallel presentation of both MHC Class I and II restricted antigens would help to generate a stronger overall anti-tumor response and long term $\mathrm{CD} 8^{+} \mathrm{T}$ cell memory via $\mathrm{CD} 4^{+} \mathrm{T}$ cell help [26,27]. In addition, it could greatly diminish the chance of tumor escape compared to using single epitope vaccines. Furthermore, the use of whole tumor cells theoretically eliminates the need to define, test and select for immunodominant epitopes. The tumor cells could be autologous, i.e. obtained from the patients, or allogeneic "off-the-shelf". The major drawback for using autologous tumor cells is that they are only useful in single patienttailored anti-tumor immunotherapies, and they could pose problems of collection, processing, reproducibility and inter-patient variability. Nevertheless, tumor cells from each patient potentially carry gene mutations encoding for unique TAAs that are important in stimulating effective and long-lasting anti-tumor responses in the patient. On the other hand, allogeneic tumor cell lines that share one or even several of the TAAs as autologous tumor cells provide a simpler method of delivering antigens in tumor immunotherapy. Allogeneic cell lines can be propagated in large quantities in cell factories and the quality can be easily assessed and monitored in good manufacturing practice (GMP) facilities.

In an attempt to compare the efficacy of peptide-pulsed to whole tumor cell-pulsed vaccinations in cancer patients, Neller et al examined the clinical outcomes of 173 published 
peer-reviewed immunotherapy trials that used either molecular defined synthetic antigens, or autologous or allogeneic tumor cells without concomitant therapies in patients with melanoma, renal cell and hepatocellular carcinomas, lung, prostate, breast, colorectal, cervical, pancreatic or ovarian cancer [28]. They found that 138 of 1711 patients $(8.1 \%)$ had objective clinical responses when whole tumor or tumor extracts were used as antigens [including DC loaded with tumor extracts, modified tumor cells or tumor mRNA], as compared to 63 of 1733 patients (3.6\%) when molecularly defined tumor antigens were used such as synthetic peptides or proteins, and viral or plasmid vectors encoding peptides or proteins $(P<0.0001$, Chi-square test). As spontaneous objective clinical responses are rarely seen in most of the cancers treated, the authors concluded that most objective clinical responses were an indication of effective immunotherapy. With the same criteria, the authors further analyzed 1601 patients who enrolled in 75 published trials for advanced metastatic melanoma, and found an objective response rate of $12.6 \%(107 / 845)$ when whole tumor undefined antigen was used compared to $6 \%(41 / 608)$ when defined antigen was administered $(P<0.001)$. Interestingly, they also found no significant difference in the response rate comparing autologous to allogeneic tumor sources $(P=0.15)$ [see reference [28] for the complete list of clinical trials]. These results provide encouragement for pursuing whole tumor antigen vaccination approaches. Obviously, because tumor cells express a large load of 'self' antigens and have evolutionally adapted to induce immune tolerance, methods to prepare whole tumor antigen become critically important to produce immunogenic vaccines.

\section{Exosomes, a form of cell-free whole tumor antigen}

Exosomes or microvesicles are 50 to $100 \mathrm{~nm}$ in diameter membrane vesicles that are generated in the multivesicular endosomes of cells, and are actively secreted by almost all cell types via exocytosis in both normal and pathological conditions. In the cancer setting, exosomes have been purified from the plasma, ascites and pleural effusions of cancer patients and found to contain tumor antigens. Tumor-derived exosomes are close replicas of the originating cells in terms of protein contents, and antigens such as HER-2/neu, EGFR2, CEA, MART-1, gp100, TRP-1, and members of the HSP family including HSP 70 and HSP 90 are commonly present in such exosomes [29-34]. A recent Phase I clinical trial investigated the use of CEA-expressing exosomes purified from the ascites of patients with advanced colorectal cancer, with or without GM-CSF administration [35]. Patients in both groups received a total of four subcutaneous immunizations at weekly intervals. Activation of CEA-specific cytotoxic T cells was detected in $75 \%$ of the patients who received both the exosome vaccine and GM-CSF, compared to $20 \%$ for patients who received exosomes alone. Methods for purifying exosomes from ovarian carcinomas have been described [36], and it would be interesting to employ this approach in the treatment of this cancer.

Interestingly, the immunogenicity of tumor-derived exosomes can be increased when they are derived from tumor cells exposed to stress conditions. For example, exosomes derived from heat-shocked tumor cells bear HSP 70 on their surface and can promote NK cell activity [37] and TNF secretion by macrophages [38]. It has also been shown that exosomes from heat-shocked lymphoma or carcinoma cells are more immunogenic than those from control untreated cells [24]. Although an attractive cell-free approach to cancer immunotherapy, exosome use will require careful optimization, as increasing evidence points to their possible immunosuppressive properties on $\mathrm{T}$ cells and monocytes. Exosomes isolated from tumor cell supernatants or directly from patients can induce T cell apoptosis in vitro through CD95 ligand (FasL) [32,39] or galectin 9 [40]. Tumor exosomes that contain membrane bound TGF- $\beta$ can also promote Treg function and inhibit IL-2 induced T cell proliferation $[41,42]$. Furthermore, tumor exosomes can reduce the cytotoxic capacity of NK cells by downregulating NKG2D[43]; impair the differentiation of myeloid precursors into DCs [21]; or induce the generation of myeloid-derived suppressor cells (MDSC) [31]. 


\title{
Killed whole tumor cells, a simple vaccine
}

\section{The question of immunogenic cell death: necrotic versus apoptotic whole tumor cells}

\author{
Whole tumor cells are a very simple approach to vaccination and can potentially be
} administered directly, without the need for dendritic cells. Live tumors cells are however poorly immunogenic and are shown to secrete soluble factors, such as vascular endothelial growth factor to suppress DCs differentiation and maturation [44], soluble Fas ligand to induce lymphocyte apoptosis [45], or soluble MICA products to inhibit NKG2D-mediated killing by immune cells [46]. In addition, IL-10 [47] and TGF- $\beta$ [48] released by tumor cells could inhibit DC and T cell functions. Galectin-1 [49] and indoleamine 2,3-dioxygenase [50] also inhibit $\mathrm{T}$ cell activation. A method to kill and at the same time to enhance the immunogenicity of tumor cells is therefore required. The question whether an apoptotic or necrotic cell is intrinsically immunogenic or tolerogenic, and indeed more suitable for use in immunotherapy, has long been debated [51-55]. Furthermore, although some differences exist between purified apoptotic and necrotic cells, their equivalent ability to mature DCs phenotypically, as well as to elicit both effective immune priming and antitumor therapeutic efficacy in vivo when presented by DCs has been demonstrated. DCs pulsed with apoptotic tumor cells have been used successfully to induce tumor vaccination [56-60]. In fact, immunogenic cell death is not a simple correlate of cell death type but depends on a large extent on the death-initiating stimulus that could cause the exposure of immunogenic factors on the cell surface or the release of immunogenic signals into the extracellular space. Some of the widely used methods of preparing whole tumor cell vaccines are discussed below.

\section{Necrotic tumor cell lysate}

A widely used and straightforward method of tumor cell preparation already used in clinical trials is necrotic whole tumor cell lysate. Whole tumor cells can be made necrotic by repetitive freeze-thaw cycles. This method generates cell material that contains a crude mixture of all kinds of cellular components including fragments of the destroyed cellular membrane, intracellular organelles such as mitochondria, and cellular RNA and DNA. Necrotic tumor cells have been shown to induce partial maturation in DC without further addition of maturation stimuli [61], probably due to the abundance of heat shock proteins (HSP), such as HSP 70 and 90, which are released from dead cells after primary necrosis [62]. HSP exposed by tumor cells are recognized by TLR4 expressed on DCs, which facilitates intracellular antigen processing and presentation [63]. The endoplasmic reticulum chaperone glucose-regulated protein 170 (GRP170), which is a member of the HSP 70 superfamily, has also been shown to bind to scavenger receptor-A on DCs and enhance the immunogenicity of tumor cells [64]. In addition, pro-inflammatory factor high mobility group box 1 (HMGB1) released during necrotic cell death [65,66], interacts with TLR4 on DCs and stimulates the processing and presentation of tumor-derived antigens [67]. Ligation of TLR4 by HMGB1 inhibits the fusion of phagosomes with lysosomes, thereby preventing the degradation of tumor antigens and facilitating their trafficking to the dedicated antigenpresenting compartment. Neutralization or knockdown of HMGB1 or knockout of TLR4 abolishes the capacity of dying tumor cells to elicit anti-tumor responses both in vitro and in vivo. Uric acid has recently received attention as a critical endogenous danger signal that is released from injured or dying cells [68-70]. It is the natural end product of the purine metabolic pathway. When cells are injured, they rapidly degrade their RNA and DNA to purines, which are converted into uric acid, resulting in accumulation of uric acid in the milieu. Shi et al showed that uric acid induces DC maturation, and enhance DC based vaccination [69]. In another study, it was also demonstrated that pretreating RIP-mOVA mice intraperitoneally with allopurinol and uricase to deplete uric acid, resulted in reduced in vivo cell division of the infused OT-1 T cells [68]. 
Tumor lysates can be administered directly without the aid of dendritic cells. In order to increase the immunogenicity of whole-cell tumor vaccines, one approach is to associate the cells with potent adjuvant haptens to provoke a strong inflammatory response. A clinical phase I trial using dinitrophenyl (DNP)-modified autologous ovarian tumor cells in stage III patients reported no acute toxicities. Some patients developed a measurable immune response, although no clinically meaningful responses were observed [71]. Alternate adjuvants can be used, including TLR agonists. In a murine glioblastoma model, subcutaneous vaccination of tumor-bearing mice with CpG-tumor lysate combination increased the number of $\mathrm{T}$ cells and activated DCs in the lymph nodes draining the vaccination site as compared to mice treated with $\mathrm{CpG}$ or tumor lysate alone. Up to 55\% of mice vaccinated with $\mathrm{CpG} / \mathrm{lysate}$ were rendered tumor-free and exhibited over 2 times greater median survival compared to mice in the $\mathrm{CpG}$ only, tumor lysate only or no treatment group $(\mathrm{P}<0.05)$ [72].

Because whole tumor lysates can be suppressive, the use of dendritic cells (DCs) provides further opportunities to manipulate the DCs during pulsing ex vivo and thus optimize their immunogenicity. For example, DCs can be polarized ex vivo with the use of interferons, Toll-like receptor agonists or $\mathrm{p} 38$ mitogen-activated protein kinase (MAPK) inhibitors to drive cytotoxic lymphocytes and Th17 effector cells at the expense of Treg [73]. Early murine vaccine studies suggested that murine bone marrow-derived DCs pulsed with whole tumor lysate were able to elicit potent anti-tumor responses and cytolytic activity in vitro and in vivo [74]. Supporting the use of whole tumor lysate as cancer vaccine is a clinical trial of 43 stage IV and 7 stage III melanoma patients vaccinated with autologous DCs pulsed with a novel allogeneic cell lysate (TRIMEL) derived from three melanoma cell lines [75]. More than $60 \%$ of the stage IV patients had positive delayed type hypersensitivity (DTH) reaction after vaccination, and the median survival of these patients was 33 months compared to 11 months for stage IV patients without DTH response. All stage III patients were DTH-positive after vaccination and remained tumor-free for a median follow-up period of 48 months (range of 33 to 64 months) [75]. To date, whole tumor lysate clinical trials in ovarian cancer patients have incorporated DCs as a vehicle for delivering TAAs. Hernando et al showed in a phase I clinical trial that patients with advanced gynecological malignancies could be effectively vaccinated with DC pulsed with keyhole limpet haemocyanin (KLH) and autologous tumor cell lysate. The DC-tumor lysate vaccine was safe and well-tolerated by the patients, and induced a delayed type IV hypersensitivity reaction (DTH) with no significant adverse effects. Three of the 8 patients exhibited remission inversion, i.e. the progression-free survival following vaccine was longer than the one prior to vaccine and after their previous chemotherapy treatment, with stable disease lasting 25 to 45 weeks [76].

Supernatants from freeze-thawed tumor cell lysate can also be used as a source of TAAs. They can be easily harvested by ultracentrifugation and filter-sterilization. The resulting supernatant contains mainly soluble tumor-derived proteins that allow for non receptormediated uptake by DCs via macro-pinocytosis [77], and subsequently processed into the MHC class II pathway. This form of antigen uptake has been however shown to lead to substantially lower cross-presentation of soluble ovalbumin as compared to cell-associated ovalbumin [78]. Supernatants may also contain soluble immunosuppressive factors produced by tumor cells as well as HSP, HMGB1, uric acid and pro-inflammatory cytokines, which help enhance the cross-presentation of TAAs.

In a pilot study at the University of Pennsylvania (UPCC-11807) we are testing partially mature DCs pulsed with autologous tumor cell lysate supernatants in subjects with recurrent ovarian cancer. DCs are pulsed with tumor freeze-thaw lysate supernatant and used intradermally without further maturation every two weeks in combination with 
immunomodulation with oral metronomic cyclophosphamide (to deplete Treg) [79] and intravenous bevacizumab (to disrupt the blood-tumor endothelial barrier) [80]. The vaccine combination has been tolerated well to date. Vaccine elicited tumor-reactive T cells as documented by tetramer analysis of HER-2-reactive T cells and IFN- $\gamma$ ELISpot analysis. Partial objective responses have been observed by RECIST criteria, one of which can be specifically attributed to the vaccine and not to the cyclophosphamide/bevacizumab combination (Coukos and colleagues, unpublished).

\section{Apoptotic whole tumor cells}

Another popular method of preparing whole tumor cell is to administer a lethal dose of ultraviolet (UV) ray irradiation to generate whole apoptotic tumor cells. During apoptosis, the asymmetry of cell plasma membrane phospholipids is lost and thus exposes the phosphatidylserine (PS) externally. The PS receptors on DC have been implicated for mediating uptake of apoptotic cells [81] and efficient cross-presentation of TAAs [82,83]. Calreticulin (CRT) is a $\mathrm{Ca}^{2+}$-binding protein present in the lumen of the endoplasmic reticulum (ER), and is involved in the modulation of $\mathrm{Ca}_{2}{ }^{+}$signaling and homeostasis [84]. Upon apoptosis initiation, CRT translocates to the dying cell surface as a crucial determinant for phagocytosis by macrophages and DCs [85]. Recently, CRT has been implicated in the immunogenicity of apoptosis elicited by anthracyclines or $\gamma$-irradiation [86]. The recognition of CRT on the dying cell surface by DCs has led to activation of DCs and the induction of CTL response in vitro and in vivo, while the immunogenicity of apoptotic cells could be abolished by CRT blocking antibodies or CRT knockdown with specific small interfering RNAs. HMGB1 is also released from apoptotic tumor cells at late stages of the dying process, and this release can be blocked by the pan-caspase inhibitor Z-VAD-fmk which delays secondary necrosis [87,88]. Late-stage apoptotic cells have been shown to stimulate mature DCs but not immature DCs, to produce pentraxin-3 (PTX3) [89]. Once secreted, PTX3 binds to the membranes of apoptotic cells, initiating DC maturation and modulating immune responses [90].

The combined administration of UV-irradiated autologous whole cells and Bacillus Calmette-Guérin (BCG) as an adjuvant has been examined in a clinical study with 81 stage III/IV metastatic melanoma patients [91]. In this trial, the patients were given the irradiated vaccine intradermally. The 5-year overall patient survival rate was approximately $45 \%$, which was superior to historical controls (at $35 \%$ and $20 \%$ for Stage III and IV, respectively). To enhance the immunogenicity of irradiated tumor cells, in a phase I trial autologous tumor cells were modified with adenovirus to secrete GM-CSF (GVAX) in patients with stage IV melanoma and advanced ovarian cancer [92,93]. Humoral and cellular antitumor immune response was detectable along with induction of brisk T cell infiltrate in metastatic lesions with extensive tumor destruction, fibrosis and edema associated with tumor-selective vasculopathy. Approximately $20 \%$ of the immunized patients achieved long-term survival in excess of 5 years, in spite of the small number of response according to RECIST criteria [94].

The GVAX approach was also tested with allogeneic cells; a series of phase I/II studies in patients with hormone-refractory prostate cancer (HRPC) tested the Prostate GVAX vaccine, which consisted of two UV-irradiated allogeneic prostate cancer cell lines - LNCaP and PC-3 - previously modified genetically to secrete GM-CSF, intended to maximize recruitment of DCs at the site of vaccine injection. Early phase data were encouraging [95-97]. In the largest of these multi-center trials, 34 of 55 patients with metastatic HRPC showed an overall median survival of 26 months that compared favorably with median survival times observed in phase II taxane chemotherapy trials in similar patients with HRPC [98-100]. However, the clinical efficacy of Prostate GVAX in prostate cancer 
patients was not confirmed in two phase III randomized studies (VITAL-1 and -2) and the program was discontinued.

UV-irradiated whole ovarian tumor cells were explored in DC based vaccines in preclinical models in ovarian cancer. UVB induced apoptosis in murine ovarian cancer cells, which was associated with mild upregulation of stress response proteins HSP 70 and GRP94. DCs pulsed with UV-irradiated whole ovarian tumor cells and administered intraperitoneally and subcutaneously resulted in modest antitumor efficacy in the mouse [101,102]. Similarly, UVB induced apoptosis in human ovarian cancer cells, and autologous PBMC-derived DCs pulsed with UVB-irradiated autologous tumor cells and matured with TNF- $\alpha$ and TRANCE elicited modest expansion of tumor-specific $\mathrm{T}$ cell precursors from peripheral blood in patients with ovarian cancer. Following three rounds of stimulation ex vivo, a low frequency of tumor-reactive T cells was detected by IFN- $\gamma$ ELISpot in approximately half the patients [103].

\section{Enhancing the immunogenicity of necrotic whole tumor cell lysates by oxidative- modification}

Hypochlorous acid $(\mathrm{HOCl})$ is a potent oxidant formed from hydrogen peroxide $\left(\mathrm{H}_{2} \mathrm{O}_{2}\right)$ and chloride ion $\left(\mathrm{Cl}^{-}\right)$in a reaction catalyzed by the neutrophil enzyme myeloperoxidase (MPO) during acute inflammation. As well as showing strong microbicidal activity, $\mathrm{HOCl}$ has been shown to enhance the immunogenicity of protein antigens by several folds via oxidation in vivo and ex vivo [104-106]. It has been demonstrated that proteins oxidized by $\mathrm{HOCl}$ are more readily taken up and processed by APCs and led to enhanced activation of antigenspecific T cells in vitro [107-110]. Therefore myeloperoxidase activity acts as a link between the innate immune response and the induction of adaptive immunity [111]. The use of $\mathrm{HOCl}$ to potentiate the immunogenicity of whole ovarian tumor cells has been previously described $[112,113]$. These were the first studies to describe the use of $\mathrm{HOCl}$, and indeed an oxidizing agent, to chemically modify whole tumor cells to enhance their immunogenicity for uptake by myeloid DCs and priming autologous tumor-specific CD4 ${ }^{+}$and $\mathrm{CD} 8^{+} \mathrm{T}$ cell responses. The well-characterized ovarian tumor cell line SKOV3, was chosen as a model source of antigens in these studies due to its overexpression of the two important ovarian TAAs, i.e. HER-2/neu and MUC1. It was found that $\mathrm{HOCl}$ induced a dose-dependent necrotic cell death in SKOV3 tumor cells after 1 hour of treatment at $37^{\circ} \mathrm{C}$ in HBSS. Approximately $99 \%$ of necrotic tumor cell death was observed at $60 \mu \mathrm{M} \mathrm{HOCl}$, and extensive cell fragmentation occurred when $65 \mu \mathrm{M} \mathrm{HOCl}$ or higher was used [113]. It was found that $\mathrm{T}$ cells stimulated with oxidized SKOV3 cells not only responded to oxidized SKOV3 as assessed by IFN- $\gamma$ ELISpot, they also responded to peptides encoding known HLA-A2 epitopes of HER-2/neu and MUC1. Since the SKOV3 cells are HLA-A2 ${ }^{-}$, this response demonstrates that oxidized cells had been taken up and cross-presented by DC. Importantly, these T cells did not respond significantly to HLA-A2 restricted melanoma MART-1 peptide thus confirming antigen specificity of the observed response. To demonstrate that the enhancement in tumor cell immunogenicity was via $\mathrm{HOCl}$ oxidation and not due primarily to necrotic cell death, SKOV3 tumor cells were killed by other means that induce cellular necrosis, i.e. heat and hydrochloric acid $(\mathrm{HCl})$ treatment, and loaded on to DCs for priming tumor-specific responses. Indeed, tumor-specific responses were only seen with $\mathrm{HOCl}$-oxidized cells, and not with heat or $\mathrm{HCl}$-treated cells. As $\mathrm{HOCl}$ and the closely related chemical $\mathrm{HCl}$ differed principally in that the former is a strong oxidizing agent, while the latter is not, these results strongly suggest that oxidation is an essential feature of the enhancement in immunogenicity observed.

This model was tested further in the ovarian cancer setting [112]. The responses of seven healthy volunteers were compared to the responses from a group of ten patients with ovarian cancer using autologous DCs loaded with oxidized SKOV3 and autologous T cells. T cells 
from all ten patients responded to the DCs pulsed with oxidized SKOV3 cells, although the average number of spots in IFN- $\gamma$ ELISPOT was lower than in the volunteer cohort $(P<$ 0.01 , MannWitney test). This might reflect differences in age distribution and general health. Pentamer staining of patients' T cells performed using a HER-2/neu peptide (E75; KIFGSLAFL)/HLA-A2 pentamer revealed that between 2 and $4 \%$ of the $\mathrm{CD}^{+} \mathrm{T}$ cells were specific for HER-2/neu E75 peptide. Importantly, T cells primed with DCs loaded with oxidized SKOV3 recognized autologous tumor cells from ascites $T$ cells that recognized the two promiscuous class II MHC restricted HER-2/neu peptides - KIFGSLAFLPESFDGDPA and GVGSPYVSRLLGICL, and autologous unmodified tumor cells in the absence of any exogenous APCs in the ELISpot assays. Importantly, T cells stimulated with oxidized melanoma cells were only specific for oxidized melanoma cells and MART-1 peptides, but not to oxidized SKOV3 ovarian tumor cells or to any ovarian TAAs. Thus the T cells stimulated by oxidized antigen remain tolerant to common self antigens that might be shared between cells of different tissue origin, but can respond to tumor-specific antigens.

We recently compared the immunogenicity of DCs pulsed with whole tumor lysate prepared using HOCL oxidation versus other common methodologies. DCs derived from elutriated peripheral blood monocytes of HLA-A2 ${ }^{+}$healthy donors treated with GM-CSF and IL-4 for more than 48 hours were pulsed with different tumor preparations including: HOCl-treated whole tumor cells; supernatants or pellets of freeze-thaw lysate of $\mathrm{HOCl}$-treated tumor cells; $\mathrm{H}_{2} \mathrm{O}_{2}$-treated whole tumor cells; UVB-irradiated whole tumor cells; supernatants of freezethaw lysate of tumor cells (no prior treatment); and whole freeze-thaw tumor cell lysate (no prior treatment). Output lymphocytes were then cocultured with T2 cells pulsed with HLAA2 restricted HER-2/neu peptide or unpulsed T2 cells overnight, and IFN- $\gamma$ in culture media was analyzed by ELISA. Confirming previous data, IFN- $\gamma$ response was significantly higher in T cells primed with DCs pulsed with HOCl-oxidized whole tumor cells (Figure 1).

The improvement in antigen immunogenicity might be explained by three possible mechanisms. First, $\mathrm{HOCl}$ can quantitatively deaminate serine and convert its side chain into an aldehyde, and some studies have shown that tagging protein antigens with such aldehydes led to significant improvement in the responses directed against the antigens [114-116]. Second, oxidation of protein antigens might allow protein unfolding (e.g. by the reduction of disulphide bonds in the protein) and therefore enhance both processing by DCs and exposure of immunogenic peptides to specific T cells [117]. The heat-shock protein, such as HSP70, might also play a role in chaperoning polypeptides that unfolded during oxidative stress to help them regain a functional structure or by directing them to a degradation pathway [118]. Third, scavenger receptors such as the lectin-like oxidized low-density lipoprotein receptor-1 (LOX-1) might be involved in the uptake of HOCl-oxidized SKOV3 tumor cells. LOX-1 is a type D scavenger receptor expressed on the surface of dendritic cells, macrophages, smooth muscle cells and platelets [119], which binds to a broad range of ligands that include oxidized low-density lipids (OxLDL), hypochlorite-modified HDL, advanced glycation end products (AGE), aged/apoptotic cells, activated platelets and bacteria [120-125]. LOX-1 has been implicated in antigen cross-presentation in DCs [126], therefore it is reasonable to postulate that it is involved in the uptake of oxidized SKOV3 by DCs and facilitate cross-presentation of ovarian TAAs to CD8 ${ }^{+} \mathrm{T}$ cells. CD36, a class B scavenger receptor expressed by macrophages and DCs for endocytic take up of OxLDL [127] and AGE-proteins [128], might also play a role in the uptake of oxidized SKOV3.

\section{Enhancing the immunogenicity of whole tumor cell lysates by viral infection}

Viral oncolysates have been utilized to increase whole tumor cell vaccine immunogenicity. Proposed mechanisms for this effect include activation of immune response through viral induction of inflammatory cytokines, and recruitment of helper $\mathrm{T}$ cells with viral immune recall. Immunogenicity of tumor cells may be enhanced through activation of "danger 
signals" by virus, or via increased uptake of tumor antigen uptake by DCs due to virustumor antigen interaction [129-134]. In the clinical setting, Freedman et al [135] tested a UV-irradiated influenza A virus oncolysate vaccine using ovarian cancer cell lines. Patients received several intraperitoneal or intrapleural infusions, and some experienced prolonged progression-free survival, with some clinical responses [136]. Schirrmacher et al utilized live inactivated low-dose Newcastle disease virus (NDV) administered with whole tumor cells, and noted improved results compared to use of tumor lysates, and led to development of specific cytotoxic T cell responses against tumor, but not virus [137]. A phase II clinical trial of NDV-modified autologous tumor cells in 31 patients with advanced disease yielded a $50 \%$ two-year survival rate [138].

We have tested the use of replication-deficient herpes simplex virus (HSV) in whole tumor vaccines. We and others have previously shown that replication-restricted oncolytic HSV strains kill tumor cells by apoptosis [139-141]. In addition, infection of epithelial cells by HSV leads to rapid up-regulation of HSP70, macrophage inflammatory protein (MIP)-1 $\beta$, interleukin (IL)-1 $\alpha$, IL-1 $\beta$ and IL-6 [142], suggesting that HSV infection may activate antigen presenting mechanisms. Animal experiments in syngeneic tumor models indicate that tumor inoculation with replication-restricted HSV result in activation of adaptive antitumor immune response. Indeed we recently demonstrated that inoculation of ICP34.5deficient HSV-1716 induced in situ tumor vaccination. This was achieved through DC activation in tumors but also through increased antigen uptake mediated through adhesive interactions between HSV glycoproteins on infected tumor cells and HSV receptors on DCs. Stress response proteins HSP70 and GRP94 were upregulated in infected tumor cells, thus increasing the antigenicity of these cells [143, 144]. Importantly, we demonstrated that engulfment of HSV-infected tumor cells induced upregulation of NKG2D ligands on DCs and enhanced their ability to activate NK cells and costimulate T cells, an effect that was abrogated by the presence of soluble NKG2D (Figure 2).

We searched for HSV strains that can induce tumor cell death but are replicationincompetent (to minimize the expression of viral antigen load by infected tumor cells). The HSV-1 genome comprises approximately 80 genes, which are expressed with temporal hierarchy following viral entry into the cell and exert diverse and temporally related functions. Immediate-early (IE) or $\alpha$ genes ICP0, ICP4, ICP22, ICP27 and ICP47 are expressed within 4 hours postinfection. Replication-incompetent ICP4 ${ }^{-}$and ICP4-ICP27 ${ }^{-}$ viruses can rapidly kill human cells [145; 146]. ICP0 in ICP4-ICP27- HSV dramatically reduces viral toxicity [145-147] We hypothesized that the use of replication-incompetent HSV-1 lacking all IE/ $\alpha$ genes except ICP0 could trigger apoptosis in tumor cells while upregulating danger signals, thereby producing strongly immunogenic whole tumor antigen. We used HSV 1106 , a replication-incompetent HSV-1 mutant lacking ICP4, ICP22, ICP27 and ICP47 but expressing the ICP0 IE/ $\alpha$ gene $[147,148]$. We demonstrated that HSV 1106 efficiently kills tumor cells by apoptosis while upregulating the expression of danger signals such as HSP70 and GRP94 (Figure 3). Tumor cells killed by HSVd106 were readily engulfed by immature DCs and enhanced DC maturation, improving tumor antigen presentation and the therapeutic efficacy of DC vaccines in vivo. We then compared the immunogenicity of DCs pulsed with HSVd106-infected cells to DCs pulsed with UVBirradiated TC- 1 cells. The growth of TC-1 tumors was significantly slower in mice vaccinated with DCs pulsed with HSV d106-treated tumor cells compared to animals vaccinated with control or UVB cells pulsed DCs. Moreover, a higher percentage of tumor free animals was observed in animals vaccinated with DCs pulsed with HSV $d 106$-infected cells compared to DCs pulsed with UVB irradiated TC-1 cells. 


\section{Dendritic cell/tumor fusion vaccines}

The use of DC/tumor cell fusion approach is first described by Gong et al [149] whereby the DCs and tumor cells were fused by the membrane destabilizing agent polyethylene glycol (PEG) or by electroporation. This novel method allows DCs to express the entire repertoire of TAAs of the fused tumor cell, and to process endogenously and present tumor epitopes via MHC class I and II pathways to activate both $\mathrm{CD} 4^{+}$and $\mathrm{CD} 8^{+} \mathrm{T}$ cells. In a preclinical study in MUC1 transgenic mice, which are unresponsive to human MUC1 antigen, administration of DC/MUC1 ${ }^{+}$tumor cell fusion vaccines generated to anti-MUC1 $\mathrm{CD} 4^{+}$and $\mathrm{CD}^{+} \mathrm{T}$ cell responses and led to tumor eradication [150-152]. Interestingly, vaccination of DCs transfected with MUC1 RNA could not reverse the unresponsiveness to MUC1 suggesting that vaccination with DC/tumor fusion vaccine only could break tumor tolerance [153].

DC/tumor fusion vaccines given in combination with recombinant IL-12 have been evaluated in a Phase I/II clinical trial involving patients with malignant brain tumors. Tumor-specific immune responses were observed, and three out of 12 patients achieved a partial response [154]. In a multiple myeloma clinical trial, patients' DCs were matured by exposure to TNF- $\alpha$ for 48 hours and fused to the patients' derived bone marrow specimens by PEG [155]. These DC-tumor fusion vaccines were then coadministered with GM-CSF. Toxicities related to the vaccines have been mild. In addition, clinical trials involving patients with breast and renal carcinoma have been completed [156]. Twenty-three patients were treated (10 breast cancer patients and 13 renal cancer patients). The vaccines were administrated subcutaneously to each patient at 3-week intervals for a total of three doses. Patients were vaccinated with $1 \times 10^{6}$ DCs pulsed with KLH protein at the time of the first fusion vaccination. At a separate site, patients were concurrently vaccinated with fusion cells. No substantial treatment-related toxic effects were observed. Of the 18 evaluable patients, 10 showed a 2 -fold or greater increase in tumor-reactive $\mathrm{CD} 4^{+}$and $\mathrm{CD} 8^{+} \mathrm{T}$ cells. Two patients with metastatic breast cancer demonstrated disease regression, and six patients (five renal cancer patients and one breast cancer patient) demonstrated disease stabilization for 3 to 9 months after the completion of vaccination.

The use of normal donors' DCs as a source of allogeneic DCs to generate the DC/tumor fusion vaccine has been investigated. A potential advantage of this strategy is that DCs generated from normal donors, as compared with cancer patients, may demonstrate greater functional activity. However, there are some disadvantages associated with this approach. First, the T-cell responses to allogeneic DC/tumor fusions are dependent on the inconsistent expression of MHC class I molecules by the tumor. Second, the absence of class II expression by tumor cells may prevent the development of an antigen-specific helper T-cell response. In a study, eight patients underwent vaccination with allogeneic DC/renal carcinoma fusions [157]. Stabilization of disease and induction of antitumor immunity was seen in a subset of patients. In a Phase I study, 24 patients underwent serial vaccination with allogeneic DC/tumor hybrids. Vaccination was well tolerated, and anti-tumor immunity was observed in a subset of patients. Two patients experienced a partial response, and eight patients demonstrated stable disease [158]. DC/ovarian tumor cell fusions have been generated and demonstrated to be able to induce anti-tumor CTL activity in vitro [159].

\section{DCs pulsed with whole tumor RNA}

Whole tumor RNA offers similar advantages as whole tumor cells in DC-based immunotherapy; there is no need to define HLA-expression in patients, and the RNA can encode for multiple epitopes, to recruit both tumor-specific $\mathrm{CD}^{+}$helper $\mathrm{T}$ cells and CD8 ${ }^{+}$ CTLs. This approach, as with whole tumor cells, is useful for forms of cancers where 
suitable tumor antigens are not yet defined. In addition, such approach may address important limitations in the procurement of autologous tumor antigen in cases where isolating large number of tumor cells is not feasible. Finally, a distinct advantage of vaccines using whole tumor RNA is the inclusion of possible stroma antigens. It has long been recognized that tumor stroma hosts cell populations with unique phenotype and tumorpromoting function such as tumor endothelium, pericytes, cancer-associated fibroblasts and tumor-associated macrophages. Tumor stroma can be a barrier to immunotherapy and its disruption can be beneficial. These cell populations express unique targets and their inclusion in immunotherapy provides synergistic results. Thus, inclusion of whole tumor stroma RNA may enhance vaccine efficacy.

DCs can be loaded with tumor RNA via three different methods: lipid-mediated transfection, passive transfection or electroporation. The problem with lipids is that they are often toxic to DCs and must be carefully optimized. Though lipids are readily available for investigation studies, the choices for clinical use are somehow limited. Passive transfection of immature DCs can occur when the DCs are co-cultured with tumor RNA in vitro. This method has been used successfully in preclinical studies $[160,161]$ and two clinical trials involving prostate and renal cell cancer patients [162,163]. More recently, electroporation has become the method of choice for introducing tumor RNA into DCs because no additional reagents are required and it is compatible with clinical use [164-166]. Special care is needed to recover the DCs after electroporation, as they can be fragile. Tumor RNA can be directly introduced into the cytoplasm of the DCs and the tumor antigens are then expressed as fulllength proteins within the cell. The assumption is that patient's own DCs would process and present the most relevant peptides to the immune system. Compared to DNA, RNA has certain important advantages. First, RNA can easily access the cellular translation machinery upon entry into the cytoplasm. Second, RNA is not subjected to cellular transcriptional regulations like DNA. Third, RNA will be rapidly degrade after electroporation and is unlikely to integrate into the host genome. However, this intrinsic instability of RNA could be a potential obstacle to clinical use, and tumor samples and RNA must be carefully handled right from the initial biopsy excision.

In a preclinical study, we compared the efficacy of whole tumor RNA to UV-irradiated apoptotic whole tumor cells as a source of TAAs for DCs-based immunotherapy [167]. We used TC- 1 cells, a mouse adenocarcinoma cell line generated by cotransfection of lung epithelial cells with HPV-16 E6 and E7 genes and H-Ras [168], which has been used to test E6 and E7-targeted tumor immunotherapy [169-171]. We showed that following electroporation with $50 \mu \mathrm{g}$ of TC-1 RNA $/ 10^{6}$ DCs, DCs expressed E6 and E7 protein in their cytoplasm for at least 4 days. The highest expression of E7 antigen was obtained at 300 $\mathrm{V}$ and 150; these settings yielded 50\% viability in electroporated DCs. DCs were incubated with UV-irradiated TC-1 cells at 1:2 ratio (DC to tumor cell) or electroporated with an amount of total RNA equivalent to two tumor cells per DC and matured with TNF- $\alpha$ and LPS. A significantly higher frequency of tumor-reactive IFN- $\gamma$ producing cells was found in spleens from animals vaccinated with RNA-DCs compared to animals vaccinated with UVDCs. In addition, a four-fold higher frequency of $\mathrm{CD}^{+} \mathrm{CD}^{+}$cells binding to $\mathrm{H} 2-\mathrm{D}^{\mathrm{b}}$ restricted HPV E7 epitope RAHYNIVTF [171] was detected in splenocytes from animals vaccinated with RNA-DCs compared to animals vaccinated with UV-DCs. In preventive vaccinations, tumor growth was significantly delayed in animals vaccinated with RNA-DCs as well as animals vaccinated with UV-DCs, but tumors were significantly smaller in mice vaccinated with RNA-DCs. Therefore our results suggested that electroporation with whole tumor cell RNA and pulsing with UV-irradiated tumor cells are both effective in eliciting anti-tumor immune response but RNA electroporation resulted in more potent tumor vaccination under these experimental conditions. Several reasons may account for our findings. First, antigen up-take may be less efficient with pulsing dying cells compared to 
RNA electroporation. Since UVB irradiation has been shown to result in a mixed population of apoptotic and necrotic tumor cells [53], it is possible that either process leads to degradation of important antigens [172], resulting in suboptimal antigen processing or presentation. Second, apoptotic DNA may bind to MHC class molecules and interfere with antigen presentation [173]. Third, although non-viral methods of DNA transfection of DCs are inefficient, the efficiency of gene transfer with RNA electroporation resembles that of transfection with recombinant viruses [174]. Finally, another advantage of RNA transfer of DC over pulsing DC with protein antigens is that endogenously synthesized antigens have better access to the class I MHC pathway [175].

Maturation protocols can modify the capability of DCs to effectively present antigens following RNA electroporation. We found that the efficacy of RNA-electroporated DCs was further enhanced by the coadminstration of $\mathrm{CpG}$ (Figure 3). Interestingly, human DCs treated with a maturation cocktail formulated with TNF, IL-1 $\beta$, IFN- $\gamma$, prostaglandin E2, and the Toll like receptor (TLR) 8 agonist R848 were able to generate an efficient immune response upon RNA electroporation; while addition of the TLR3 ligand poly(I:C) to the maturation cocktail rendered DCs unable to express proteins from electroporated RNA [176]. Indeed, the formulation of appropriate maturation cocktails is one of the challenges that faces the generation of effective DC-based vaccines for clinical use [177].

The potential of tumor RNA as cancer vaccines has been used for treatment in melanoma, prostate and renal cell carcinoma with some success. In a phase I trial with metastatic renal cell carcinoma patients, 6 of 7 patients receiving the renal tumor RNA-transfected DCs vaccine demonstrated an expansion of tumor-specific $\mathrm{T}$ cells after immunization [163]. These $\mathrm{T}$ cell exhibited a polyclonal reactivity against a broad set of renal TAAs, including telomerase reverse transcriptase, G250, and oncofetal antigen. Although most patients underwent secondary therapies after vaccination, the tumor-related mortality of the study subjects was low with only 3 of 10 patients dying from disease after a mean follow-up of 19.8 months. In another phase I/II study, melanoma patients were administered mature autologous DCs transfected with autologous tumor mRNA that had been previously cryopreserved [178]. The vaccine was well-tolerated and 9 of 19 patients had vaccinespecific T cell responses, while 8 of 18 patients had positive DTH reaction. The authors compared two routes of vaccinations - intradermal and intranodal - and found the former more potent in inducing tumor-specific T cell response ( 7 of 10 compared to 3 of 12 patients). In a recent clinical trial, 15 melanoma patients were directly injected intradermally with autologous naked mRNA (without DCs) plus GM-CSF, and some patients exhibited anti-tumor humoral responses after immunization [179]. More studies are needed to clarify the efficacy of direct RNA injection in tumor immunotherapy.

\section{Conclusion}

The use of whole tumor cell preparations in tumor immunotherapy is a very promising approach and obviates some important limitations in vaccine development. Whole tumor cells are a good source of TAAs and can induce simultaneous CTLs and CD4 ${ }^{+} \mathrm{T}$ helper cell activation. There are several approaches to preparing whole tumor cell preparations. Because tumor lysate can be intrinsically suppressive to DC activation in vitro and in vivo, interventions to prevent DC suppression are critically needed. Although DCs pulsed with UV-irradiated tumor cells is a common method to prepare whole tumor vaccines, in our hands proved to be inferior to RNA electroporation or methods we developed to increase tumor cell immunogenicity, comprising infection with replication-incompetent HSV or oxidation with $\mathrm{HOCl}$. These will ultimately need to be tested in clinical studies. 


\section{Acknowledgments}

This work was supported by NIH P50-CA083638 Ovarian Cancer SPORE; The Ovarian Cancer Research Fund in support of the Cooperative Ovarian Group for Immunotherapy; and The Ovarian Cancer Immunotherapy Initiative.

\section{References}

1. Zhang L, Conejo-Garcia JR, Katsaros D, et al. Intratumoral T cells, recurrence, and survival in epithelial ovarian cancer. N Engl J Med. 2003; 348:203-13. [PubMed: 12529460]

2. Halapi E, Yamamoto Y, Juhlin C, Jeddi-Tehrani M, et al. Restricted T cell receptor V-beta and Jbeta usage in $\mathrm{T}$ cells from interleukin-2-cultured lymphocytes of ovarian and renal carcinomas. Cancer Immunol Immunother. 1993; 36:191-7. [PubMed: 8439980]

3. Fisk B, Blevins TL, Wharton JT, Ioannides CG. Identification of an immunodominant peptide of HER-2/neu protooncogene recognized by ovarian tumor-specific cytotoxic T lymphocyte lines. J Exp Med. 1995; 181:2109-17. [PubMed: 7539040]

4. Peoples GE, Goedegebuure PS, Smith R, et al. Breast and ovarian cancer-specific cytotoxic T lymphocytes recognize the same HER2/neu-derived peptide. Proc Natl Acad Sci U S A. 1995; 92:432-6. [PubMed: 7831305]

5. Ioannides CG, Platsoucas CD, Rashed S, et al. Tumor cytolysis by lymphocytes infiltrating ovarian malignant ascites. Cancer Res. 1991; 51:4257-65. [PubMed: 1868446]

6. Freedman RS, Tomasovic B, Templin S, et al. Large-scale expansion in interleukin-2 of tumorinfiltrating lymphocytes from patients with ovarian carcinoma for adoptive immunotherapy. $\mathrm{J}$ Immunol Methods. 1994; 167:145-60. [PubMed: 8308273]

7. Ioannides CG, Freedman RS, Platsoucas CD, Rashed S, Kim YP. Cytotoxic T cell clones isolated from ovarian tumor-infiltrating lymphocytes recognize multiple antigenic epitopes on autologous tumor cells. J Immunol. 1991; 146:1700-7. [PubMed: 1704404]

8. Adams SF, Levine DA, Cadungog MG, et al. Intraepithelial T cells and tumor proliferation: Impact on the benefit from surgical cytoreduction in advanced serous ovarian cancer. Cancer. 2009; 115:2891-902. [PubMed: 19472394]

9. Clarke B, Tinker AV, Lee C, et al. Intraepithelial T cells and prognosis in ovarian carcinoma: novel associations with stage, tumor type, and BRCA1 loss. Mod Pathol. 2009; 223:393-402. [PubMed: 19060844]

10. Hamanishi J, Mandai M, Iwasaki M, et al. Programmed cell death 1 ligand 1 and tumor-infiltrating CD8+ T lymphocytes are prognostic factors of human ovarian cancer. Proc Natl Acad Sci U S A. 2007; 104:3360-5. [PubMed: 17360651]

11. Sato E, Olson SH, Ahn J, et al. Intraepithelial CD8+ tumor-infiltrating lymphocytes and a high $\mathrm{CD} 8+/$ regulatory $\mathrm{T}$ cell ratio are associated with favorable prognosis in ovarian cancer. Proc Natl Acad Sci U S A. 2005; 102:18538-43. [PubMed: 16344461]

12. Shah CA, Allison KH, Garcia RL, Gray HJ, Goff BA, Swisher EM. Intratumoral T cells, tumorassociated macrophages, and regulatory T cells: Association with p53 mutations, circulating tumor DNA and survival in women with ovarian cancer. Gynecol Oncol. 2008; 109:215-9. [PubMed: 18314181]

13. Tomsova M, Melichar B, Sedlakova I, Steiner I. Prognostic significance of CD3+ tumorinfiltrating lymphocytes in ovarian carcinoma. Gynecol Oncol. 2008; 108:415-20. [PubMed: 18037158]

14. Stumpf M, Hasenburg A, Riener MO, et al. Intraepithelial CD8-positive T lymphocytes predict survival for patients with serous stage III ovarian carcinomas: Relevance of clonal selection of T lymphocytes. Br J Cancer. 2009; 101:1513-21. [PubMed: 19861998]

15. Milne K, Kobel M, Kalloger SE, et al. Systematic analysis of immune infiltrates in high-grade serous ovarian cancer reveals CD20, FoxP3 and TIA-1 as positive prognostic factors. PLoS One. 2009; 4:e6412. [PubMed: 19641607]

16. Nakano O, Sato M, Naito Y, et al. Proliferative activity of intratumoral CD8(+) T-lymphocytes as a prognostic factor in human renal cell carcinoma: clinicopathologic demonstration of antitumor immunity. Cancer Res. 2001; 61:5132-6. [PubMed: 11431351] 
17. Schumacher K, Haensch W, Roefzaad C, Schlag PM. Prognostic significance of activated CD8+ T cell infiltrations within esophageal carcinomas. Cancer Res. 2001; 61:3932-6. [PubMed: 11358808]

18. Vesalainen S, Lipponen P, Talja M, Syrjänen K. Histological grade, perineural infiltration, tumourinfiltrating lymphocytes and apoptosis as determinants of long-term prognosis in prostatic adenocarcinoma. Eur J Immunol. 1994; 30A:1797-803.

19. Marrogi AJ, Munshi A, Merogi AJ, et al. Study of tumor infiltrating lymphocytes and transforming growth factor-beta as prognostic factors in breast carcinoma. Int J Cancer. 1997; 74:492-501. [PubMed: 9355970]

20. Naito Y, Saito K, Shiiba K, Ohuchi A, Saigenji K. CD8+ T cells infiltrated within cancer cell nests as a prognostic factor in human colorectal cancer. Cancer Res. 1998; 58:3491-4. [PubMed: 9721846]

21. Galon J, Costes A, Sanchez-Cabo F, et al. Type, density, and location of immune cells within human colorectal tumors predict clinical outcome. Science. 2006; 313:1960-4. [PubMed: 17008531]

22. Pages F, Berger A, Camus M, et al. Effector memory T cells, early metastasis, and survival in colorectal cancer. N Engl J Med. 2005; 353:2654-66. [PubMed: 16371631]

23. Novellino L, Castelli C, Parmiani G. A listing of human tumor antigens recognized by T cells: March 2004 update. Cancer Immunol Immunother. 2005; 54:187-207. [PubMed: 15309328]

24. Brossart P, Wirths S, Stuhler G, et al. Induction of cytotoxic T-lymphocyte responses in vivo after vaccinations with peptide-pulsed dendritic cells. Blood. 2000; 96:3102-8. [PubMed: 11049990]

25. Disis ML, Goodell V, Schiffman K, Knutson KL. Humoral epitope-spreading following immunization with a HER-2/neu peptide based vaccine in cancer patients. J Clin Immunol. 2004; 24:571-8. [PubMed: 15359116]

26. Toes RE, Ossendorp F, Offringa R, Melief CJ. CD4 T cells and their role in antitumor immune responses. J Exp Med. 1999; 189:753-6. [PubMed: 10049938]

27. Zajac AJ, Blattman JN, Murali-Krishna K, et al. Viral immune evasion due to persistence of activated T Cells without effector function. J Exp Med. 1998; 188:2205-13. [PubMed: 9858507]

28. Neller MA, López JA, Schmidt CW. Antigens for cancer immunotherapy. Semin Immunol. 2008; 20:286-95. [PubMed: 18951039]

29. Andre F, Schartz NEC, Movassagh M, et al. Malignant effusions and immunogenic tumourderived exosomes. The Lancet. 2002; 360:295-305.

30. Huber V, Fais S, Iero M, et al. Human colorectal cancer cells induce t-cell death through release of proapoptotic microvesicles: Role in immune escape. Gastroenterology. 2005; 128:1796-804. [PubMed: 15940614]

31. Valenti R, Huber V, Filipazzi P, et al. Human tumor-released microvesicles promote the differentiation of myeloid cells with transforming growth factor-\{beta $\}$-mediated suppressive activity on t lymphocytes. Cancer Res. 2006; 66:9290-8. [PubMed: 16982774]

32. Andreola G, Rivoltini L, Castelli C, Huber V, Perego P, Deho P, Squarcina P, Accornero P, Lozupone F, Lugini L, Stringaro A, Molinari A, Arancia G, Gentile M, Parmiani G, Fais S. Induction of lymphocyte apoptosis by tumor cell secretion of fasL-bearing microvesicles. J Exp Med. 2002; 195:1303-16. [PubMed: 12021310]

33. Mears R, Craven RA, Hanrahan S, et al. Proteomic analysis of melanoma-derived exosomes by two-dimensional polyacrylamide gel electrophoresis and mass spectrometry. Proteomics. 2004; 4:4019-31. [PubMed: 15478216]

34. Hegmans JPJJ, Bard MPL, Hemmes A, et al. Proteomic analysis of exosomes secreted by human mesothelioma cells. Am J Pathol. 2004; 164:1807-15. [PubMed: 15111327]

35. Dai S, Wei D, Wu Z, et al. Phase i clinical trial of autologous ascites-derived exosomes combined with GM-CSF for colorectal cancer. Mol Ther. 2008; 16:782-90. [PubMed: 18362931]

36. Navabi H, Croston D, Hobot J, Clayton A, Zitvogel L, Jasani B, Bailey-Wood R, Wilson K, Tabi $\mathrm{Z}$, Mason MD, Adams M. Preparation of human ovarian cancer ascites-derived exosomes for a clinical trial. Blood Cells Mol Dis. 2005; 35:149-52. [PubMed: 16061407] 
37. Gastpar R, Gehrmann M, Bausero MA, et al. Heat shock protein 70 surface-positive tumor exosomes stimulate migratory and cytolytic activity of natural killer cells. Cancer Res. 2005; 65:5238-47. [PubMed: 15958569]

38. Vega VL, Rodriguez-Silva M, Frey T, et al. Hsp70 translocates into the plasma membrane after stress and is released into the extracellular environment in a membrane-associated form that activates macrophages. J Immunol. 2008; 180:4299-307. [PubMed: 18322243]

39. Dai S, Wan T, Wang B, et al. More efficient induction of HLA-A*0201-restricted and carcinoembryonic antigen (CEA)-specific CTL response by immunization with exosomes prepared from heat-stressed CEA-positive tumor cells. Clin Cancer Res. 2005; 11:7554-63. [PubMed: 16243831]

40. Clayton A, Mitchell JP, Court J, Mason MD, Tabi Z. Human tumor-derived exosomes selectively impair lymphocyte responses to interleukin-2. Cancer Res. 2007; 67:7458-66. [PubMed: 17671216]

41. Clayton A, Mitchell JP, Court J, et al. Human tumor-derived exosomes down-modulate NKG2Dexpression. J Immunol. 2008; 180:7249-58. [PubMed: 18490724]

42. Liu C, Yu S, Zinn K, et al. Murine mammary carcinoma exosomes promote tumor growth by suppression of NK cell function. J Immunol. 2006; 176:1375-85. [PubMed: 16424164]

43. Yu S, Liu C, Su K, et al. Tumor exosomes inhibit differentiation of bone marrow dendritic cells. J Immunol. 2007; 178:6867-75. [PubMed: 17513735]

44. Dikov MM, Oyama T, Cheng P, et al. Vascular endothelial growth factor effects on nuclear factorkappaB activation in hematopoietic progenitor cells. Cancer Res. 2001; 61:2015-21. [PubMed: 11280761]

45. Rabinowich H, Reichert TE, Kashii Y, Gastmann BR, Whiteside TL. Lymphocyte apoptosis induced by Fas ligand-expressing ovarian carcinoma cells. Implications for altered expression of $\mathrm{T}$ cell receptor in tumor-associated lymphocytes. J Clin Invest. 1998; 101:2579-88. [PubMed: 9616229]

46. Groh V, Wu J, Yee C, Spies T. Tumour-derived soluble MIC ligands impair expression of NKG2D and T-cell activation. Nature. 2002; 419:734-8. [PubMed: 12384702]

47. Loercher AE, Nash MA, Kavanagh JJ, Platsoucas CD, Freedman RS. Identification of an IL-10producing HLA-DR-negative monocyte subset in the malignant ascites of patients with ovarian carcinoma that inhibits cytokine protein expression and proliferation of autologous T cells. $\mathrm{J}$ Immunol. 1999; 163:6251-60. [PubMed: 10570318]

48. Li MO, Wan YY, Sanjabi S, Robertson AK, Flavell RA. Transforming growth factor-beta regulation of immune responses. Annu Rev Immunol. 2006; 24:99-146. [PubMed: 16551245]

49. Rubinstein DB, Karmely M, Ziv R, et al. MUC1/X protein immunization enhances cDNA immunization in generating anti-MUC1 alpha/beta junction antibodies that target malignant cells. Cancer Res. 2006; 66:11247-53. [PubMed: 17145869]

50. Uyttenhove C, Pilotte L, Theate I, et al. Evidence for a tumoral immune resistance mechanism based on tryptophan degradation by indoleamine 2,3-dioxygenase. Nat Med. 2003; 9:1269-74. [PubMed: 14502282]

51. Bhardwaj N. Processing and presentation of antigens by dendritic cells: Implications for vaccines. Trends Mol Med. 2001; 7:388-94. [PubMed: 11530333]

52. Chen Z, Moyana T, Saxena A, et al. Efficient antitumor immunity derived from maturation of dendritic cells that had phagocytosed apoptotic/necrotic tumor cells. Int J Cancer. 2001; 93:53948. [PubMed: 11477558]

53. Kotera Y, Shimizu K, Mule JJ. Comparative analysis of necrotic and apoptotic tumor cells as a source of antigen(s) in dendritic cell-based immunization. Cancer Res. 2001; 61:8105-9. [PubMed: 11719436]

54. Sauter B, Albert ML, Francisco L, et al. Consequences of cell death: Exposure to necrotic tumor cells, but not primary tissue cells or apoptotic cells, induces the maturation of immunostimulatory dendritic cells. J Exp Med. 2000; 191:423-34. [PubMed: 10662788]

55. Basu S, Binder RJ, Suto R, Anderson KM, Srivastava PK. Necrotic but not apoptotic cell death releases heat shock proteins, which deliver a partial maturation signal to dendritic cells and activate the NF-kappa B pathway. Int Immunol. 2000; 12:1539-46. [PubMed: 11058573] 
56. Henry F, Boisteau O, Bretaudeau L, et al. Antigen-presenting cells that phagocytose apoptotic tumor-derived cells are potent tumor vaccines. Cancer Res. 1999; 59:3329-32. [PubMed: 10416588]

57. Hoffmann TK, Meidenbauer N, Dworacki G, Kanaya H, Whiteside TL. Generation of tumorspecific T-lymphocytes by cross-priming with human dendritic cells ingesting apoptotic tumor cells. Cancer Res. 2000; 60:3542-9. [PubMed: 10910067]

58. Russo V, Tanzarella S, Dalerba P, et al. Dendritic cells acquire the MAGE-3 human tumor antigen from apoptotic cells and induce a class I-restricted T cell response. Proc Natl Acad Sci U S A. 2000; 97:2185-90. [PubMed: 10681453]

59. Schnurr M, Scholz C, Rothenfusser S, et al. Apoptotic pancreatic tumor cells are superior to cell lysates in promoting cross-priming of cytotoxic T cells and activate NK and gamma-delta $\mathrm{T}$ cells. Cancer Res. 2002; 62:2347-52. [PubMed: 11956095]

60. Shaif-Muthana M, McIntyre C, Sisley K, Rennie I, Murray A. Dead or alive: Immunogenicity of human melanoma cells when presented by dendritic cells. Cancer Res. 2000; 60:6441-7. [PubMed: 11103811]

61. Sauter B, Albert ML, Francisco L, et al. Consequences of cell death: Exposure to necrotic tumor cells, but not primary tissue cells or apoptotic cells, induces the maturation of immunostimulatory dendritic cells. J Exp Med. 2000; 191:423-34. [PubMed: 10662788]

62. Somersan S, Larsson M, Fonteneau JF, et al. Primary tumor tissue lysates are enriched in heat shock proteins and induce the maturation of human dendritic cells. J Immunol. 2001; 167:484452. [PubMed: 11673488]

63. Asea A, Kraeft SK, Kurt-Jones EA, et al. HSP70 stimulates cytokine production through a CD14dependant pathway, demonstrating its dual role as a chaperone and cytokine. Nat Med. 2000; 6:435-42. [PubMed: 10742151]

64. Wang XY, Arnouk H, Chen X, et al. Extracellular targeting of endoplasmic reticulum chaperone glucose-regulated protein 170 enhances tumor immunity to a poorly immunogenic melanoma. $\mathrm{J}$ Immunol. 2006; 177:1543-51. [PubMed: 16849461]

65. Scaffidi P, Misteli T, Bianchi ME. Release of chromatin protein HMGB1 by necrotic cells triggers inflammation. Nature. 2002; 418:191-5. [PubMed: 12110890]

66. Wang H, Bloom O, Zhang M, et al. HMG-1 as a late mediator of endotoxin lethality in mice. Science. 1999; 285:248-251. [PubMed: 10398600]

67. Apetoh L, Ghiringhelli F, Tesniere A, et al. Toll-like receptor 4-dependent contribution of the immune system to anticancer chemotherapy and radiotherapy. Nat Med. 2007; 13:1050-9. [PubMed: 17704786]

68. Hu DE, Moore AM, Thomsen LL, Brindle KM. Uric acid promotes tumor immune rejection. Cancer Res. 2004; 64:5059-62. [PubMed: 15289304]

69. Shi Y, Evans JE, Rock KL. Molecular identification of a danger signal that alerts the immune system to dying cells. Nature. 2003; 425:516-21. [PubMed: 14520412]

70. Chen CJ, Shi Y, Hearn A, et al. MYD88-dependent IL-1 receptor signaling is essential for gouty inflammation stimulated by monosodium urate crystals. J Clin Invest. 2006; 116:2262-71. [PubMed: 16886064]

71. Berd D, Kairys J, Dunton C, et al. Autologous, hapten-modified vaccine as a treatment for human cancers. Semin Oncol. 1998; 25:646-53. [PubMed: 9865679]

72. Wu A, Oh S, Gharagozlou S, et al. In vivo vaccination with tumor cell lysate plus CpG oligodeoxynucleotides eradicates murine glioblastoma. J Immunother. 2007; 30:789-97. [PubMed: 18049330]

73. Cannon MJ, O'Brien TJ. Cellular immunotherapy for ovarian cancer. Expert Opin Biol Ther. 2009; 9:677-88. [PubMed: 19456205]

74. Fields RC, Shimizu K, Mulé JJ. Murine dendritic cells pulsed with whole tumor lysates mediate potent antitumor immune responses in vitro and in vivo. Proc Natl Acad Sci U S A. 1998; 95:9482-7. [PubMed: 9689106]

75. Lopez MN, Pereda C, Segal G, et al. Prolonged survival of dendritic cell-vaccinated melanoma patients correlates with tumor-specific delayed type IV hypersensitivity response and reduction of tumor growth factor beta-expressing T cells. J Clin Oncol. 2009; 27:945-52. [PubMed: 19139436] 
76. Hernando JJ, Park TW, Kübler K, et al. Vaccination with autologous tumour antigen-pulsed dendritic cells in advanced gynaecological malignancies: clinical and immunological evaluation of a phase I trial. Cancer Immunol Immunother. 2002; 51:45-52. [PubMed: 11845259]

77. Watts C. Capture and processing of exogenous antigens for presentation on MHC molecules. Annu Rev Immunol. 1997; 15:821-50. [PubMed: 9143708]

78. Li M, Davey GM, Sutherland RM, et al. Cell-associated ovalbumin is cross-presented much more efficiently than soluble ovalbumin in vivo. J Immunol. 2001; 166:6099-103. [PubMed: 11342628]

79. Ghiringhelli F, Menard C, Puig PE, et al. Metronomic cyclophosphamide regimen selectively depletes CD4+CD25+ regulatory $\mathrm{T}$ cells and restores $\mathrm{T}$ and $\mathrm{NK}$ effector functions in end stage cancer patients. Cancer Immunol Immunother. 2007; 56:641-8. [PubMed: 16960692]

80. Kandalaft LE, Facciabene A, Buckanovich RJ, Coukos G. Endothelin b receptor, a new target in cancer immune therapy. Clin Cancer Res. 2009; 15:4521-8. [PubMed: 19567593]

81. Fadok VA, Bratton DL, Rose DM, et al. A receptor for phosphatidylserine-specific clearance of apoptotic cells. Nature. 2000; 405:85-90. [PubMed: 10811223]

82. Larsson M, Fonteneau JF, Bhardwaj N. Dendritic cells resurrect antigens from dead cells. Trends Immunol. 2001; 22:141-8. [PubMed: 11286729]

83. Jenne L, Arrighi JF, Jonuleit H, Saurat JH, Hauser C. Dendritic cells containing apoptotic melanoma cells prime human CD8+ T cells for efficient tumor cell lysis. Cancer Res. 2000; 60:4446-52. [PubMed: 10969791]

84. Coppolino MG, Woodside MJ, Demaurex N, et al. Calreticulin is essential for integrin-mediated calcium signalling and cell adhesion. Nature. 1997; 386:843-7. [PubMed: 9126744]

85. Obeid M, Tesniere A, Ghiringhelli F, et al. Calreticulin exposure dictates the immunogenicity of cancer cell death. Nat Med. 2007; 13:54-61. [PubMed: 17187072]

86. Obeid M, Panaretakis T, Joza N, et al. Calreticulin exposure is required for the immunogenicity of gamma-irradiation and UVC light-induced apoptosis. Cell Death Differ. 2007; 14:1848-50. [PubMed: 17657249]

87. Tian J, Avalos AM, Mao SY, et al. Toll-like receptor 9-dependent activation by DNA-containing immune complexes is mediated by HMGB1 and RAGE. Nat Immunol. 2007; 8:487-96. [PubMed: 17417641]

88. Bell CW, Jiang W, Reich CF 3rd, Pisetsky DS. The extracellular release of HMGB1 during apoptotic cell death. Am J Physiol Cell Physiol. 2006; 291:C1318-25. [PubMed: 16855214]

89. Rovere P, Peri G, Fazzini F, et al. The long pentraxin ptx 3 binds to apoptotic cells and regulates their clearance by antigen-presenting dendritic cells. Blood. 2000; 96:4300-6. [PubMed: 11110705]

90. Baruah P, Propato A, Dumitriu IE, et al. The pattern recognition receptor PTX3 is recruited at the synapse between dying and dendritic cells, and edits the cross-presentation of self, viral, and tumor antigens. Blood. 2006; 107:151-8. [PubMed: 16166594]

91. Baars A, Claessen AME, van den Eertwegh AJM, et al. Skin tests predict survival after autologous tumor cell vaccination in metastatic melanoma: Experience in 81 patients. Ann Oncol. 2000; 11:965-70. [PubMed: 11038032]

92. Hodi FS, Butler M, Oble DA, et al. Immunologic and clinical effects of antibody blockade of cytotoxic T lymphocyte-associated antigen 4 in previously vaccinated cancer patients. Proc Natl Acad Sci U S A. 2008; 105:3005-10. [PubMed: 18287062]

93. Hodi FS, Mihm MC, Soiffer RJ, et al. Biologic activity of cytotoxic t lymphocyte-associated antigen 4 antibody blockade in previously vaccinated metastatic melanoma and ovarian carcinoma patients. Proc Natl Acad Sci U S A. 2003; 100:4712-7. [PubMed: 12682289]

94. Dranoff G. Tragets of protective tumor immunity in Cancer Vaccines. Annals NY Acad Science. 2009:74-80.

95. Eager R, John N. GM-CSF gene-transduced tumor vaccines. Mol Ther. 2005; 12:18-27. [PubMed: 15963916]

96. Simons J, Carducci M, Mikhak BL, et al. Phase I/II trial of an allogeneic cellular immunotherapy in hormone-naïve prostate cancer. Clin Cancer Res. 2006; 12:3394-401. [PubMed: 16740763] 
97. Small E, Sacks N, Nemunaitis J, et al. Granulocyte macrophage colony-stimulating factorsecreting allogeneic cellular immunotherapy for hormone-refractory prostate cancer. Clin Cancer Res. 2007; 13:3883-91. [PubMed: 17606721]

98. Petrylak DP, Macarthur RB, O'Connor J, et al. Phase I trial of docetaxel with estramustine in androgen-independent prostate cancer. J Clin Oncol. 1999; 17:958-67. [PubMed: 10071290]

99. Savarese DM, Halabi S, Hars V, et al. Phase II study of docetaxel, estramustine, and low-dose hydrocortisone in men with hormone-refractory prostate cancer: A final report of CALGB 9780. Cancer and Leukemia Group B. J Clin Oncol. 2001; 19:2509-16. [PubMed: 11331330]

100. Small E, Tchekmedyian N, Rini B, Fong L, Lowy I, Allison J. A pilot trial of CTLA-4 blockade with human anti-CTLA-4 in patients with hormone-refractory prostate cancer. Clin Cancer Res. 2007; 13:1810-5. [PubMed: 17363537]

101. Benencia F, Courreges MC, Coukos G. Whole tumor antigen vaccination using dendritic cells: Comparison of RNA electroporation and pulsing with UV-irradiated tumor cells. J Transl Med. 2008; 6:21. [PubMed: 18445282]

102. Courreges MC, Benencia F, Conejo-Garcia JR, Zhang L, Coukos G. Preparation of apoptotic tumor cells with replication-incompetent HSV augments the efficacy of dendritic cell vaccines. Cancer Gene Ther. 2006; 13:182-93. [PubMed: 16138121]

103. Schlienger K, Chu CS, Woo EY, et al. Trance- and CD40 ligand-matured dendritic cells reveal MHC class I-restricted T cells specific for autologous tumor in late-stage ovarian cancer patients. Clin Cancer Res. 2003; 9:1517-27. [PubMed: 12684428]

104. Allison MED, Fearon DT. Enhanced immunogenicity of aldehyde-bearing antigens: A possible link between innate and adaptive immunity. Eur J Immunol. 2000; 30:2881-7. [PubMed: 11069070]

105. Marcinkiewicz J, Chain BM, Olszowska E, Olszowski S, Zgliczynski JM. Enhancement of immunogenic properties of ovalbumin as a result of its chlorination. Int J Biochem. 1991; 23:1393-5. [PubMed: 1761149]

106. Marcinkiewicz J, Olszowska E, Olszowski S, Zgliczynski J. Enhancement of trinitrophenylspecific humoral response to TNP proteins as the result of carrier chlorination. Immunology. 1992; 76:385-8. [PubMed: 1382040]

107. Callahan MK, Chaillot D, Jacquin C, Clark PR, Ménoret A. Differential acquisition of antigenic peptides by HSP70 and HSC70 under oxidative conditions. J Biol Chem. 2002; 277:33604-9. [PubMed: 12114509]

108. Stark JM. Immunological adjuvance of metabolic origin: oxidative stress, postulated impaired function of thiol proteases and immunogenicity. Scand J Immunol. 1998; 48:475-9. [PubMed: 9822254]

109. Reth M. Hydrogen peroxide as second messenger in lymphocyte activation. Nat Immunol. 2002; 3:1129-34. [PubMed: 12447370]

110. Tatla S, Woodhead V, Foreman JC, Chain BM. The role of reactive oxygen species in triggering proliferation and IL-2 secretion in T cells. Free Radic Biol Med. 1999; 26:14-24. [PubMed: 9890636]

111. Marcinkiewicz J. Neutrophil chloramines: Missing links between innate and acquired immunity. Immunol Today. 1997; 18:577-80. [PubMed: 9425735]

112. Chiang CL, Ledermann JA, Egla A, Elizabeth B, Katz DR, Chain BM. Oxidation of ovarian epithelial cancer cells by hypochlorous acid enhances immunogenicity and stimulates $\mathrm{T}$ cells that recognize autologous primary tumor. Clin Cancer Res. 2008; 14:4898-907. [PubMed: 18676764]

113. Chiang CL, Ledermann JA, Rad AN, Katz DR, Chain BM. Hypochlorous acid enhances immunogenicity and uptake of allogeneic ovarian tumor cells by dendritic cells to cross-prime tumor-specific T cells. Cancer Immunol Immunother. 2006; 55:1384-95. [PubMed: 16463039]

114. Anderson MM, Hazen SL, Hsu FF, Heinecke JW. Human neutrophils employ the myeloperoxidase-hydrogen peroxide-chloride system to convert hydroxy-amino acids into glycolaldehyde, 2-hydroxypropanal, and acrolein. A mechanism for the generation of highly reactive alpha-hydroxy and alpha,beta-unsaturated aldehydes by phagocytes at sites of inflammation. J Clin Invest. 1997; 99:424-32. [PubMed: 9022075] 
115. Anderson MM, Requena JR, Crowley JR, Thorpe SR, Heinecke JW. The myeloperoxidase system of human phagocytes generates Nepsilon-(carboxymethyl)lysine on proteins: A mechanism for producing advanced glycation end products at sites of inflammation. J Clin Invest. 1999; 104:103-13. [PubMed: 10393704]

116. Hazen SL, Hsu FF, Mueller DM, Crowley JR, Heinecke JW. Human neutrophils employ chlorine gas as an oxidant during phagocytosis. J Clin Invest. 1996; 98:1283-9. [PubMed: 8823292]

117. Carrasco-Marín SE, Paz-Miguel J, López-Mato P, Alvarez-Domínguez C, Leyva-Cobián F. Oxidation of defined antigens allows protein unfolding and increases both proteolytic processing and exposes peptide epitopes which are recognized by specific T cells. Immunology. 1998; 95:314-21. [PubMed: 9824492]

118. Feder ME, Hofmann GE. Heat-shock proteins, molecular chaperones, and the stress response: evolutionary and ecological physiology. Annu Rev Physiol. 1999; 61:243-82. [PubMed: 10099689]

119. Chen M, Masaki T, Sawamura T. Lox-1, the receptor for oxidized low-density lipoprotein identified from endothelial cells: Implications in endothelial dysfunction and atherosclerosis. Pharmacol Ther. 2002; 95:89-100. [PubMed: 12163130]

120. Kakutani M, Masaki T, Sawamura T. A platelet-endothelium interaction mediated by lectin-like oxidized low-density lipoprotein receptor-1. Proc Natl Acad Sci U S A. 2000; 97:360-4. [PubMed: 10618423]

121. Oka K, Sawamura T, Kikuta K, et al. Lectin-like oxidized low-density lipoprotein receptor 1 mediates phagocytosis of aged/apoptotic cells in endothelial cells. Proc Natl Acad Sci U S A. 1998; 95:9535-40. [PubMed: 9689115]

122. Moriwaki H, Kume N, Sawamura T, et al. Ligand specificity of lox-1, a novel endothelial receptor for oxidized low density lipoprotein. Arterioscler Thromb Vasc Biol. 1998; 18:1541-7. [PubMed: 9763524]

123. Jono T, Miyazaki A, Nagai R, et al. Lectin-like oxidized low density lipoprotein receptor-1 (lox-1) serves as an endothelial receptor for advanced glycation end products (age). FEBS Letters. 2002; 511:170-4. [PubMed: 11821070]

124. Shimaoka T, Kume N, Minami M, et al. Lox-1 supports adhesion of gram-positive and gramnegative bacteria. J Immunol. 2001; 166:5108-14. [PubMed: 11290792]

125. Marsche G, Levak-Frank S, Quehenberger O, et al. Identification of the human analog of SR-BI and LOX-1 as receptors for hypochlorite-modified high density lipoprotein on human umbilical venous endothelial cells. FASEB J. 2001; 15:1095-7. [PubMed: 11292679]

126. Delneste Y, Magistrelli G, Gauchat JF, et al. Involvement of LOX-1 in dendritic cell-mediated antigen cross-presentation. Immunity. 2002; 17:353-62. [PubMed: 12354387]

127. Marsche G, Zimmermann R, Horiuchi S, et al. Class B scavenger receptors CD36 and SR-BI are receptors for hypochlorite-modified low density lipoprotein. J Biol Chem. 2003; 278:47562-70. [PubMed: 12968020]

128. Ohgami N, Nagai R, Miyazaki A, et al. Scavenger receptor class b type i-mediated reverse cholesterol transport is inhibited by advanced glycation end products. J Biol Chem. 2001; 276:13348-55. [PubMed: 11278947]

129. Austin FC, Boone CW. Virus augmentation of the antigenicity of tumor cell extracts. Adv Cancer Res. 1979; 30:301-45. [PubMed: 92181]

130. Melcher A, Todryk S, Hardwick N, et al. Tumor immunogenicity is determined by the mechanism of cell death via induction of heat shock protein expression. Nat Med. 1998; 4:581-7. [PubMed: 9585232]

131. Schirrmacher V, Ahlert T, Probstle T, et al. Immunization with virus-modified tumor cells. Semin Oncol. 1998; 25:677-96. [PubMed: 9865682]

132. Arroyo PJ, Bash JA, Wallack MK. Active specific immunotherapy with vaccinia colon oncolysate enhances the immunomodulatory and antitumor effects of interleukin-2 and interferon alpha in a murine hepatic metastasis model. Cancer Immunol Immunother. 1990; 31:305-11. [PubMed: 2376048]

133. Bash JA, Wallack MK. Vaccinia virus oncolysates in the treatment of malignant melanoma. Cancer Treat Res. 1988; 43:177-90. [PubMed: 2908574] 
134. Sinkovics JG. Viral oncolysates as human tumor vaccines. Int Rev Immunol. 1991; 7:259-87. [PubMed: 1663989]

135. Freedman RS, Ioannides CG, Mathioudakis G, Platsoucas CD. Novel immunologic strategies in ovarian carcinoma. Am J Obstet Gynecol. 1992; 167:1470-8. [PubMed: 1332480]

136. Ioannides CG, Den Otter W. Concepts in immunotherapy of cancer: Introduction. In Vivo. 1991; 5:551-2. [PubMed: 1810436]

137. Schirrmacher V. Clinical trials of antitumor vaccination with an autologous tumor cell vaccine modified by virus infection: Improvement of patient survival based on improved antitumor immune memory. Cancer Immunol Immunother. 2005; 54:587-98. [PubMed: 15838708]

138. Mobus V, Horn S, Stock M, Schirrmacher V. Tumor cell vaccination for gynecological tumors. Hybridoma. 1993; 12:543-7. [PubMed: 7905460]

139. Coukos G, Makrigiannakis A, Kang EH, et al. Oncolytic herpes simplex virus-1 lacking ICP34.5 induces p53-independent death and is efficacious against chemotherapy-resistant ovarian cancer. Clin Cancer Res. 2000; 6:3342-53. [PubMed: 10955822]

140. Aubert M, O'Toole J, Blaho JA. Induction and prevention of apoptosis in human hep-2 cells by herpes simplex virus type 1. J Virol. 1999; 73:10359-170. [PubMed: 10559354]

141. Galvan V, Roizman B. Herpes simplex virus 1 induces and blocks apoptosis at multiple steps during infection and protects cells from exogenous inducers in a cell-type-dependent manner. Proc Natl Acad Sci U S A. 1998; 95:3931-6. [PubMed: 9520470]

142. Mikloska Z, Danis Vic A, Adams S, et al. In vivo production of cytokines and beta (C-C) chemokines in human recurrent herpes simplex lesions--do herpes simplex virus-infected keratinocytes contribute to their production? J Infect Dis. 1998; 177:827-38. [PubMed: 9534953]

143. Benencia F, Coukos G. Biological therapy with oncolytic herpesvirus. Adv Exp Med Biol. 2008; 622:221-33. [PubMed: 18546631]

144. Benencia F, Courreges MC, Fraser NW, Coukos G. Herpes virus oncolytic therapy reverses tumor immune dysfunction and facilitates tumor antigen presentation. Cancer Biol Ther. 2008; 7:1194-205. [PubMed: 18458533]

145. Samaniego LA, Neiderhiser L, DeLuca NA. Persistence and expression of the herpes simplex virus genome in the absence of immediate-early proteins. J Virol. 1998; 72:3307-20. [PubMed: 9525658]

146. Hobbs WE 2nd, DeLuca NA. Perturbation of cell cycle progression and cellular gene expression as a function of herpes simplex virus ICP0. J Virol. 1999; 73:8245-55. [PubMed: 10482575]

147. Jugovic P, Hill AM, Tomazin R, Ploegh H, Johnson DC. Inhibition of major histocompatibility complex class I antigen presentation in pig and primate cells by herpes simplex virus type 1 and 2 ICP47. J Virol. 1998; 72:5076-84. [PubMed: 9573278]

148. Samaniego L, Wu N, DeLuca N. The herpes simplex virus immediate-early protein ICP0 affects transcription from the viral genome and infected-cell survival in the absence of icp4 and ICP27. J Virol. 1997; 71:4614-25. [PubMed: 9151855]

149. Gong J, Chen D, Kashiwaba M, Kufe D. Induction of antitumor activity by immunization with fusions of dendritic and carcinoma cells. Nat Med. 1997; 3:558-61. [PubMed: 9142127]

150. Gong J, Chen D, Kashiwaba M, et al. Reversal of tolerance to human MUC1 antigen in MUC1 transgenic mice immunized with fusions of dendritic and carcinoma cells. Proc Natl Acad Sci U S A. 1998; 95:6279-83. [PubMed: 9600956]

151. Koido S, Tanaka Y, Chen D, Kufe D, Gong J. The kinetics of in vivo priming of CD4 and CD8 T cells by dendritic/tumor fusion cells in muc1-transgenic mice. J Immunol. 2002; 168:2111-7. [PubMed: 11859096]

152. Tanaka Y, Koido S, Chen D, et al. Vaccination with allogeneic dendritic cells fused to carcinoma cells induces antitumor immunity in muc1 transgenic mice. Clin Immunol. 2001; 101:192-200. [PubMed: 11683578]

153. Koido S, Kashiwaba M, Chen D, et al. Induction of antitumor immunity by vaccination of dendritic cells transfected with MUC1 RNA. J Immunol. 2000; 165:5713-9. [PubMed: 11067929] 
154. Kikuchi T, Akasaki Y, Abe T, et al. Vaccination of glioma patients with fusions of dendritic and glioma cells and recombinant human interleukin 12. J Immunother. 2004; 27:452-9. [PubMed: 15534489]

155. Avigan, D.; Vasir, B.; Wu, Z., et al. Dendritic cell myeloma fusions stimulate anti-tumor immunity: Results from pre-clinical studies and a clinical trial. ASH Annual Meeting; 2004. p. 751Abstracts

156. Avigan D, Vasir B, Gong J, et al. Fusion cell vaccination of patients with metastatic breast and renal cancer induces immunological and clinical responses. Clin Cancer Res. 2004; 10:4699-708. [PubMed: 15269142]

157. Märten A, Renoth S, Heinicke T, et al. Allogeneic dendritic cells fused with tumor cells: Preclinical results and outcome of a clinical phase i/ii trial in patients with metastatic renal cell carcinoma. Hum Gene Ther. 2003; 14:483-94. [PubMed: 12691613]

158. Avigan DE, Vasir B, George DJ, et al. Phase I/II study of vaccination with electrofused allogeneic dendritic cells/autologous tumor-derived cells in patients with stage iv renal cell carcinoma. J Immunother. 2007; 30:749-61. [PubMed: 17893567]

159. Gong J, Nikrui N, Chen D, et al. Fusions of human ovarian carcinoma cells with autologous or allogeneic dendritic cells induce antitumor immunity. J Immunol. 2000; 165:1705-11. [PubMed: 10903782]

160. Nair SK, Heiser A, Boczkowski D, et al. Induction of cytotoxic T cell responses and tumor immunity against unrelated tumors using telomerase reverse transcriptase RNA transfected dendritic cells. Nat Med. 2000; 6:1011-7. [PubMed: 10973321]

161. Heiser A, Maurice MA, Yancey DR, et al. Human dendritic cells transfected with renal tumor RNA stimulate polyclonal T-cell responses against antigens expressed by primary and metastatic tumors. Cancer Res. 2001; 61:3388-93. [PubMed: 11309297]

162. Heiser A, Coleman D, Dannull J, et al. Autologous dendritic cells transfected with prostatespecific antigen RNA stimulate CTL responses against metastatic prostate tumors. J Clin Invest. 2002; 109:409-17. [PubMed: 11828001]

163. Su Z, Dannull J, Heiser A, et al. Immunological and clinical responses in metastatic renal cancer patients vaccinated with tumor RNA-transfected dendritic cells. Cancer Res. 2003; 63:2127-33. [PubMed: 12727829]

164. Milazzo C, Reichardt VL, Muller MR, Grunebach F, Brossart P. Induction of myeloma-specific cytotoxic T cells using dendritic cells transfected with tumor-derived RNA. Blood. 2003; 101:977-82. [PubMed: 12393470]

165. Muller MR, Grunebach F, Nencioni A, Brossart P. Transfection of dendritic cells with RNA induces CD4- and CD8-mediated T cell immunity against breast carcinomas and reveals the immunodominance of presented T cell epitopes. J Immunol. 2003; 170:5892-6. [PubMed: 12794115]

166. Siegel S, Wagner A, Kabelitz D, et al. Induction of cytotoxic T-cell responses against the oncofetal antigen-immature laminin receptor for the treatment of hematologic malignancies. Blood. 2003; 102:4416-23. [PubMed: 12869512]

167. Benencia F, Courreges M, Coukos G. Whole tumor antigen vaccination using dendritic cells: Comparison of RNA electroporation and pulsing with UV-irradiated tumor cells. J Transl Med. 2008; 6:21. [PubMed: 18445282]

168. Lin KY, Guarnieri FG, Staveley-O'Carroll KF, et al. Treatment of established tumors with a novel vaccine that enhances major histocompatibility class II presentation of tumor antigen. Cancer Res. 1996; 56:21-6. [PubMed: 8548765]

169. Gunn GR, Zubair A, Peters C, et al. Two Listeria monocytogenes vaccine vectors that express different molecular forms of human papilloma virus-16 (HPV-16) E7 induce qualitatively different $\mathrm{T}$ cell immunity that correlates with their ability to induce regression of established tumors immortalized by HPV-16. J Immunol. 2001; 167:6471-9. [PubMed: 11714814]

170. Hussain SF, Paterson Y. CD4+CD25+ regulatory T cells that secrete TGFbeta and IL-10 are preferentially induced by a vaccine vector. J Immunother. 2004; 27:339-46. [PubMed: 15314542] 
171. Lamikanra A, Pan ZK, Isaacs SN, Wu TC, Paterson Y. Regression of established human papillomavirus type 16 (HPV-16) immortalized tumors in vivo by vaccinia viruses expressing different forms of HPV-16 E7 correlates with enhanced CD8(+) T-cell responses that home to the tumor site. J Virol. 2001; 75:9654-64. [PubMed: 11559797]

172. Labarriere N, Bretaudeau L, Gervois N, et al. Apoptotic body-loaded dendritic cells efficiently cross-prime cytotoxic T lymphocytes specific for NA17-A antigen but not for Melan-A/MART-1 antigen. Int J Cancer. 2002; 101:280-6. [PubMed: 12209980]

173. Filaci G, Contini P, Fravega M, et al. Apoptotic DNA binds to HLA class II molecules inhibiting antigen presentation and participating in the development of anti-inflammatory functional behavior of phagocytic macrophages. Hum Immunol. 2003; 64:9-20. [PubMed: 12507810]

174. Kim CJ, Prevette T, Cormier J, et al. Dendritic cells infected with poxviruses encoding MART-1/ Melan A sensitize T lymphocytes in vitro. J Immunother. 1997; 20:276-86. [PubMed: 9220317]

175. Rea D, Johnson ME, Havenga MJ, Melief CJ, Offringa R. Strategies for improved antigen delivery into dendritic cells. Trends Mol Med. 2001; 7:91-4. [PubMed: 11286763]

176. Zobywalski A, Javorovic M, Frankenberger B, et al. Generation of clinical grade dendritic cells with capacity to produce biologically active IL-12p70. J Transl Med. 2007; 5:18. [PubMed: 17430585]

177. Gilboa E. DC-based cancer vaccines. J Clin Invest. 2007; 117:1195-203. [PubMed: 17476349]

178. Kyte JA, Mu L, Aamdal S, et al. Phase I/II trial of melanoma therapy with dendritic cells transfected with autologous tumor-mRNA. Cancer Gene Ther. 2006; 13:905-18. [PubMed: 16710345]

179. Weide B, Carralot JP, Reese A, et al. Results of the first Phase I/II clinical vaccination trial with direct injection of mRNA. J Immunother. 2008; 31:180-8. [PubMed: 18481387] 


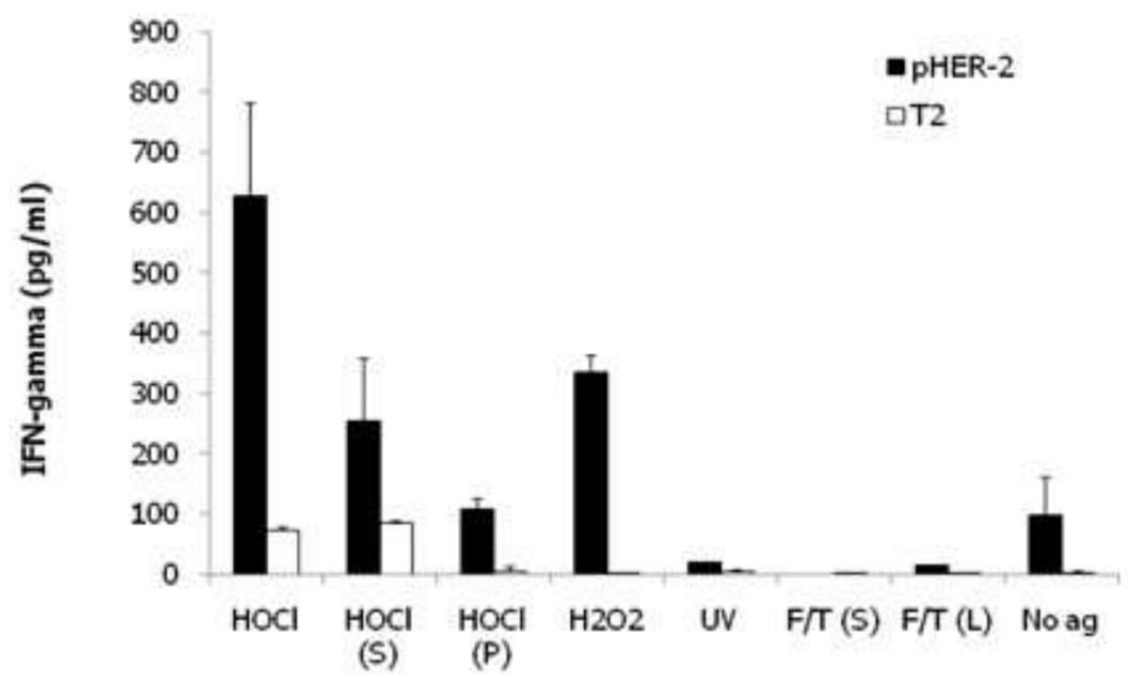

Figure 1.

Comparison of immunogenicity of human DCs pulsed with different lysate preparations of SKOV3 ovarian cancer cells. Autologous DC from HLA-A2+ donor, derived from elutriated peripheral blood monocytes treated with GM-CSF and IL-4 for 48 hours, were pulsed with lysates of SKOV3 cells, which express Her2, for 4 hours and matured overnight with LPS and IFN- $\gamma$. DCs were then used to prime naive, autologous lymphocytes for 10 days. Output $\mathrm{T}$ cells were incubated overnight with T2 cells pulsed with HLA-A2 restricted Her2 peptide or unpulsed T2 cells. The relative presence of functional Her-2 reactive lymphocytes was measured by IFN- $\gamma$ ELISA. DCs were pulsed with freeze-thaw lysates of HOCl-treated whole tumor cells $(\mathrm{HOCl})$; supernatants $[\mathrm{HOCl}(\mathrm{S})]$ or pellets $[\mathrm{HOCl}(\mathrm{P})]$ of freeze-thaw lysate of $\mathrm{HOCl}$-treated tumor cells; freeze-thaw lysates of $\mathrm{H}_{2} \mathrm{O}_{2}$-treated whole tumor cells (H2O2); supernatants of freeze-thaw lysate of UVB-irradiated tumor cells (UV); and supernatants $[\mathrm{F} / \mathrm{T}(\mathrm{S})]$ or whole freeze-thaw tumor cell lysate $[\mathrm{F} / \mathrm{T}(\mathrm{L})]$. Unpulsed DCs (No ag) were also matured with LPS and IFN- $\gamma$. Error bars represent data from duplicate coculture wells. T cell priming against Her2 was highest in T cells incubated with DCs pulsed with HOCl-oxidized whole tumor cells. 


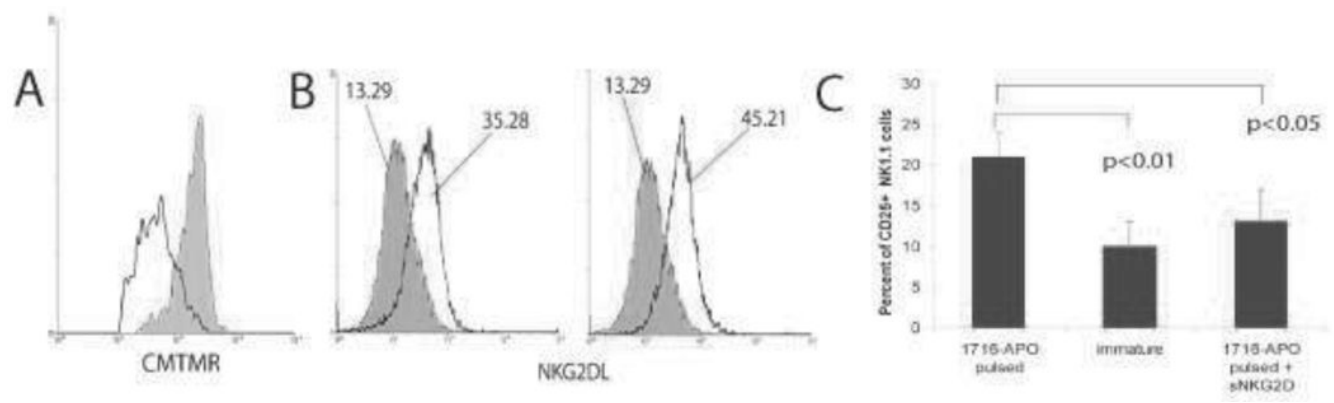

Figure 2.

Activation of mouse DCs by tumor cells killed with oncolytic replication-restricted HSV. (A) Tumor-infiltrating CD8+ T cells isolated from ID8 tumors were incubated with bone marrow derived DCs that were pulsed with ID8 ovarian tumor cells killed by HSV-1716 (clear) or DCs pulsed with UV-irradiated ID8 cells (gray). DCs pulsed with viral oncolysate induce more pronounced proliferation of CD8+ T cells, as assessed by CMTMR dilution. (B) Flow cytometry analysis of NKG2D ligand (NKG2DL) expression in (left) unpulsed immature DCs (gray) or unpulsed DCs matured with LPS (clear), and (right) control unpulsed DCs (gray) and DCs pulsed with ID8 cells killed by HSV-1716 (clear). NKG2DL was detected through NKG2D/FC chimera (R\&D). (C) Percent of CD25+ activated NK cells as determined by flow cytometry analysis 48 hours after incubation with immature DCs or DCs pulsed with apoptotic cells killed with HSV-1716 (1716-APO), in the presence or absence of soluble NKG2D $(5 \mathrm{~g} / \mathrm{ml})$. 

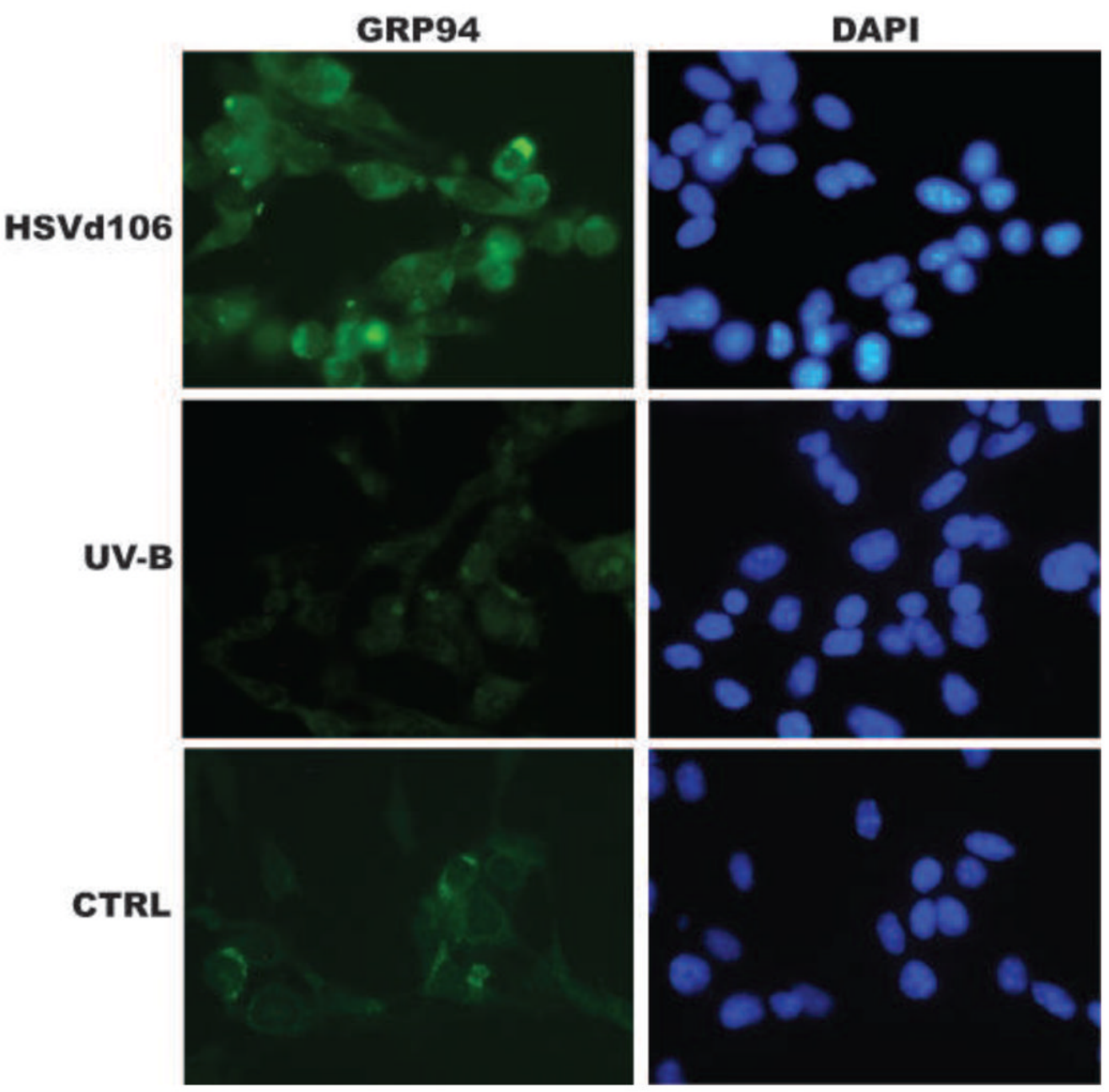

Figure 3.

Upregulation of stress response protein GRP94 in TC-1 cells 24 hours after infection with HSV $d 106$ (1 MOI), TC-1 cells irradiated with UV-B and control TC-1 cells (CTRL).

Magnification 200x. 


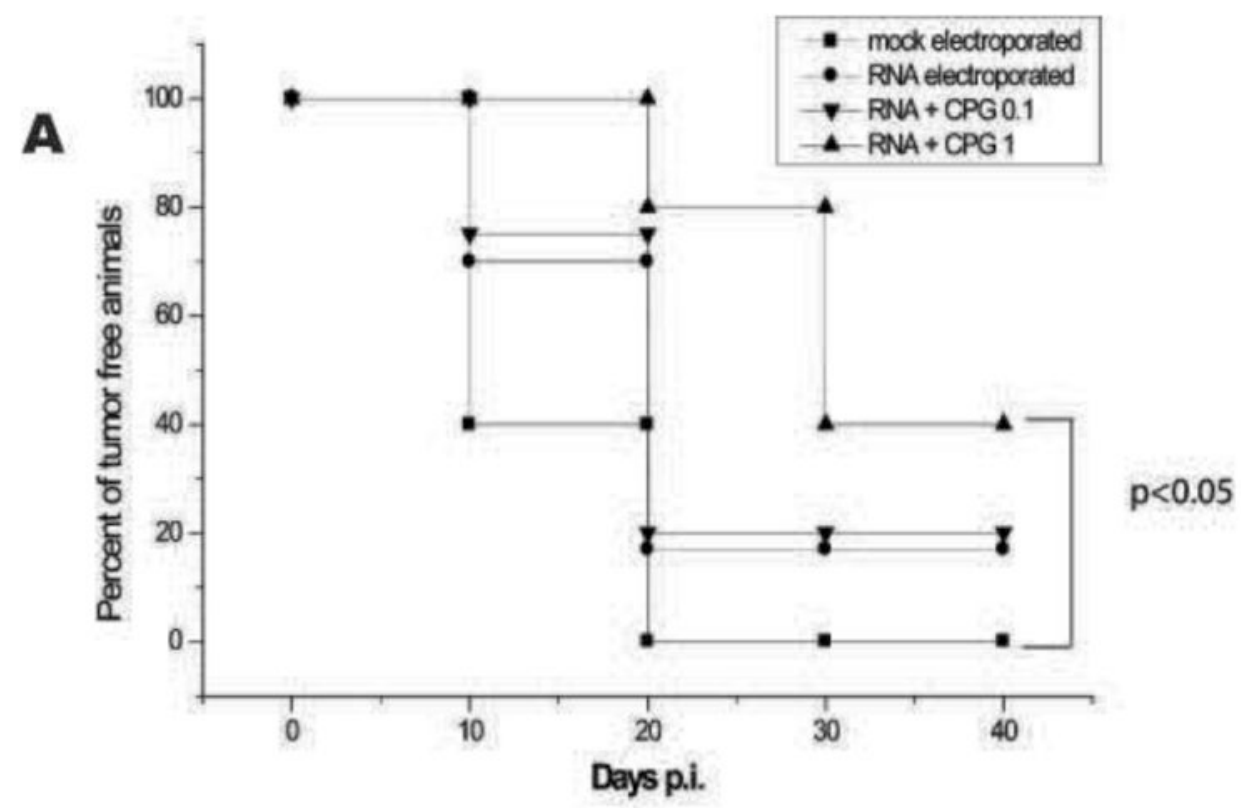

$\mathbf{B}$

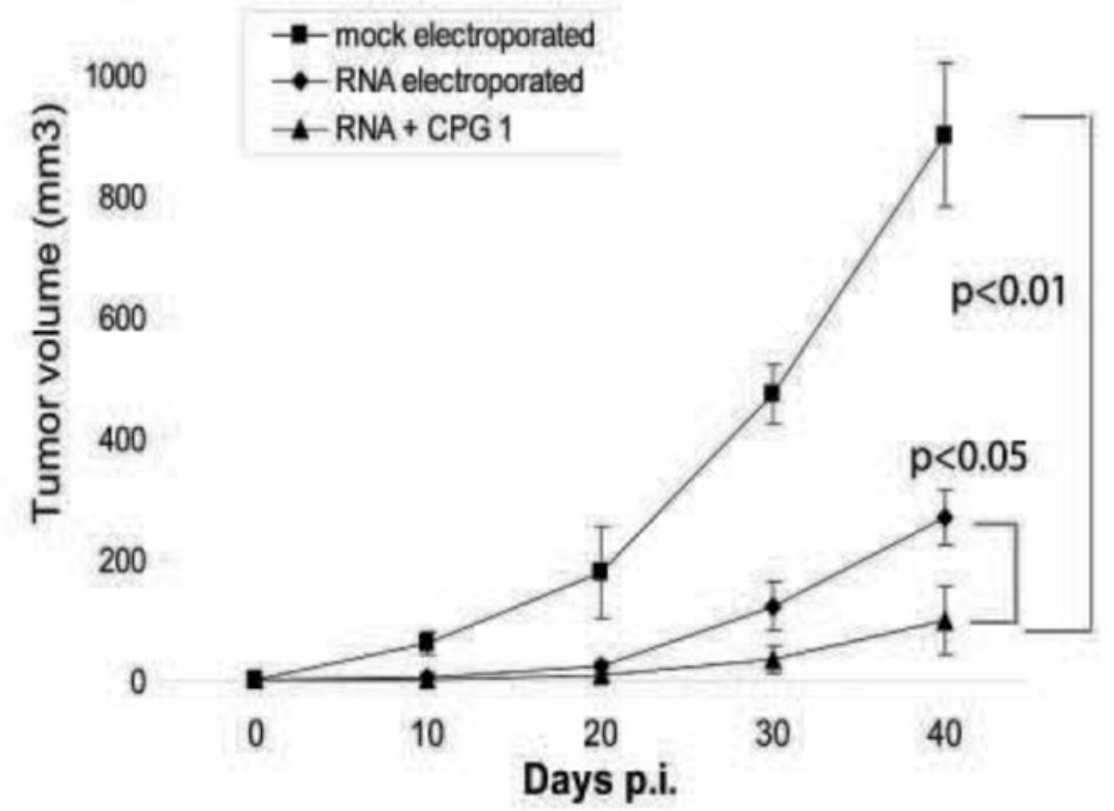

Figure 4.

Antitumoral effect of DCs electroporated with whole tumor RNA in the C56BL/6 mouse. (A) Kaplan-Meier curves depict tumor-free percentages in mice vaccinated prophylactically with DCs electroporated with total RNA extracted from TC-1 cells (50 $\mu \mathrm{g}$ of TC-1 RNA/10 6 DCs in $200 \mu \mathrm{L}$ at $300 \mathrm{mV}$ and capacitance of $150 \mu \mathrm{F}$ ) with or without $\mathrm{CpG}$ (5"

TCCATGACGTTCCTGATGCT-3"). CpG was added at 0.1 or $1 \mu \mathrm{g} / \mathrm{ml}$ to the RNA mixture immediately before DC electroporation. CpG enhanced DC efficacy in a dose-dependent manner, reducing significantly tumor incidence. (B) Growth of flank TC-1 tumors in the above animals. 